IZA DP No. 7838

Incarceration and Crime: Evidence from

California's Public Safety Realignment Reform

Magnus Lofstrom

Steven Raphael

December 2013 


\title{
Incarceration and Crime: Evidence from California's Public Safety Realignment Reform
}

\author{
Magnus Lofstrom \\ Public Policy Institute of California \\ and IZA \\ Steven Raphael \\ University of California, Berkeley \\ and IZA
}

\section{Discussion Paper No. 7838 \\ December 2013}

\author{
IZA \\ P.O. Box 7240 \\ 53072 Bonn \\ Germany \\ Phone: +49-228-3894-0 \\ Fax: +49-228-3894-180 \\ E-mail: iza@iza.org
}

\begin{abstract}
Any opinions expressed here are those of the author(s) and not those of IZA. Research published in this series may include views on policy, but the institute itself takes no institutional policy positions. The IZA research network is committed to the IZA Guiding Principles of Research Integrity.

The Institute for the Study of Labor (IZA) in Bonn is a local and virtual international research center and a place of communication between science, politics and business. IZA is an independent nonprofit organization supported by Deutsche Post Foundation. The center is associated with the University of Bonn and offers a stimulating research environment through its international network, workshops and conferences, data service, project support, research visits and doctoral program. IZA engages in (i) original and internationally competitive research in all fields of labor economics, (ii) development of policy concepts, and (iii) dissemination of research results and concepts to the interested public.
\end{abstract}

IZA Discussion Papers often represent preliminary work and are circulated to encourage discussion. Citation of such a paper should account for its provisional character. A revised version may be available directly from the author. 
IZA Discussion Paper No. 7838

December 2013

\section{ABSTRACT \\ Incarceration and Crime: Evidence from California's Public Safety Realignment Reform}

We evaluate the effect of perhaps the largest exogenous decline in a state's incarceration rate in U.S. history on local crime rates. We assess the effects of a recent reform in California that caused a sharp and permanent reduction in the state's incarceration rate. We exploit the large variation across California counties in the effect of this reform on county-specific prison incarceration rates. We find very little evidence of an effect of the large reduction in incarceration rates on violent crime and evidence of modest effects on property crime, auto theft in particular. These effects are considerably smaller than existing estimates in the literature based on panel data for periods of time when the U.S. incarceration rate was considerably lower. We corroborate theses cross-county results with a synthetic-cohort analysis of state crime rates in California. This state-wide analysis confirms our findings from the county-level analysis. In conjunction with existing published research, the results from this study support the hypothesis of a crime-prison effect that diminishes with the scale of incarceration.

JEL Classification: K40, K42, H11

Keywords: crime, incapacitation, incarceration, prison, realignment, reform

Corresponding author:

Magnus Lofstrom

Public Policy Institute of California

500 Washington Street, Suite 600

San Francisco, CA 94111

USA

E-mail: Lofstrom@ppic.org

\footnotetext{
* We thank Mia Bird, Justin McCrary and seminar participants at the Public Policy Institute of California for feedback on early drafts of this project. Brandon Martin provided excellent research assistance. This research was supported by a grant from the Smith Richardson Foundation.
} 


\section{Introduction}

Since the 1970's, the United States has experienced a pronounced increase in the proportion of its residents incarcerated in a state or federal prison. Between 1975 and 2007, the U.S. incarceration rate increased four and half time, from 111 inmates per 100,000 residents to 506 . If one adds the 773,000 jails inmates to the total for 2007 , the overall incarceration rates increases to 762 per 100,000 . This is by far the highest incarceration rate in the world (Raphael and Stoll 2013).

In every year since 2007, the U.S. incarceration rate has declined. As of December 31, 2012, the imprisonment rate for state and federal prisons stood at 480 per 100,000 (Carson and Golinelli 2013), roughly comparable to the incarceration rate in 2003 . For the most part, these declines are driven by sentencing reforms at the state level designed to scale back the use of incarceration in punishing and rehabilitating convicted offenders. Various factors have provided impetuses for these reforms. First, the fiscal impacts of the recent deep economic recession have induced state leaders to scour their budgets for potential savings. While corrections expenditures are often third or fourth on the list of budget categories commanding general fund dollars, the explosive growth in these expenditures in recent decades have come under increasing scrutiny.

Second, there is a palpable, bipartisan shift in public opinion regarding the use of prison as a tool for crime control and punishment. While liberal scholars and think tanks have deemed the use of incarceration in the U.S. as excessive for years (see for example Jacobson 2006, Mauer 2006, Western 2006), several prominent conservatives have recently voiced similar 
opinions. In a recent op-ed in the Washington Post, ${ }^{1}$ former speaker of the House Newt Gingrich and the former Republican leader of the California State Assembly Pat Nolan argue that states could reduce current incarceration rates with little impact on public safety. The conservative movement advocating corrections reform has even progressed to the point of an active and very visible national advocacy group titled Right on Crime. ${ }^{2}$ One harbinger of the degree to which this shift is broad-based can be found in the election results for a 2012 California ballot initiative that essentially narrowed the scope of application of California's three-strikes sentencing law. This ballot proposition passed in all of California's 58 counties, with a minimum level of support of 52 percent in Madera County and a maximum level of support of 84.5 percent in San Francisco (the unweighted average across all counties was 66 percent). ${ }^{3}$ Another such harbinger of the shift in public opinion is evident in the recent announcement by the U.S. Attorney General Eric Holder that federal prosecutors will no longer seek mandatory minimum sentences for low-level, non-violent drug offenders tried in federal court.

Third, one large state, California has essentially been forced by a federal court to reduce the size of its prison population. The reform driving the reduction went into effect in late 2011 and by the end of the 2012 decreased the state's incarceration rates to a level not seen since the early 1990s.

A key question of interest to both policy makers as well as criminal justice researchers concerns the effects of these reforms on crime rates. There is a large body of research

\footnotetext{
${ }^{1}$ Gingrich, Newt and Pat Nolan, "Prison Reform: A Smart Way for States to Save Money and Lives," the Washington Post, January 7, 2011.

${ }^{2}$ See http://www.rightoncrime.com/, accessed on August 2, 2013.

${ }^{3}$ Final official elections results come from the California Secretary of State, http://www.sos.ca.gov/elections/sov/2012-general/, accessed on August 2, 2013.
} 
assessing the effects of changes in incarceration on crime. This research tends to find that incarcerating a convicted criminal offender does on average reduce crime through incapacitation and deterrence, with the lion's share of the reduction operating through incapacitation. However, this research also documents a crime-prison effect that exhibits diminishing returns to scale at quite low levels of incarceration, and very small incapacitation/deterrence effects at the incarceration rates that currently characterize most U.S. states.

In this paper, we evaluate the effect of perhaps the largest exogenous decline in a state's incarceration rate in U.S. history on local crime rates. We assess the effects of a recent reform in California that caused a sharp and permanent reduction in the state's incarceration rate. Implemented on October 1, 2011, California's Public Safety Realignment (AB109) eliminated the practice of sending technical parole violators back to state prison, defined a series of offenses and offenders that are now punished with jail sentences rather than prison sentences, and greatly increased the ability and incentives for local criminal justice systems to make use of alternative sentences that rely less heavily on incarceration.

We exploit the large variation across California counties in the effect of this reform on county-specific prison incarceration rates. We find very little evidence of an effect of the large reduction in incarceration rates on violent crime and evidence of modest effects on property crime, auto theft in particular. These effects are considerably smaller than existing estimates in the literature based on panel data for periods of time when the U.S. incarceration rate was considerably lower. Moreover, these estimates are much smaller than those from similar studies of Italian prisoner releases that use methods comparable to those employed here. We 
corroborate theses cross-county results with a synthetic-cohort analysis of state crime rates in California relative to other states with comparable pre-intervention crime trends. This statewide analysis confirms our findings. In conjunction with existing published research, the results from this study strongly support the hypothesis of a crime-prison effect that diminishes quite rapidly with the scale of incarceration.

\section{Prior Research on the Crime-Prison Relationship}

The relationship between incarceration and crime is driven by three primary causal channels. First, prisons incapacitate the criminally active. Second, the threat of prison may deter criminal activity. Finally, prison may be transformative, either through rehabilitation or through a hardening of prison inmates, factors likely to alter future offending of former prison inmates. While the first two factors theoretically induce a contemporaneous negative relationship between criminal offending and incarceration levels, the latter channel likely induces a distributed lagged effect of incarceration on crime that can be either positive or negative.

A large body of research by criminologists based on inmate interviews estimates incapacitation effects through retrospective surveys. Careful reviews of this research summarize the findings in terms of the average number of serious felonies prevented per prison year served. The corpus of this body of research finds annual incapacitation effects of 10 to 20 fewer serious felony offenses (Marvell and Moody 1994, Spelman 1994, 2000). Most of this research, however, employs prisoner surveys fielded during the 1970s and 1980s, years when the US incarceration rate was much lower than contemporary levels. With the large 
increase in U.S. incarceration rates, the average age of prison inmates has increased as has the proportion of inmates convicted of less serious offenses. Given the tendency of offending to decline with age, and heterogeneity in the criminal propensities of prison inmates (Raphael and Stoll 2013, Chapter 7), one might expect lower incapacitation effects from studies employing more recent data.

The study by Owens (2009) suggests that this is the case. Owens analyzes the criminal activity of convicted felons who serve less time as the result of the 2001 discontinuance of the practice of considering juvenile records when sentencing adult offenders in the state of Maryland. Owens finds incapacitation effects roughly one-fifth the size of the incapacitation effects from earlier research.

Several studies exploit the unusual Italian practice of periodic, large, and sudden prisoner releases through collective clemencies and collective pardons to study the relationship between incarceration and crime. Barbarino and Mastrobuoni (2012) construct a panel data set of crime and incarceration rates that vary by year and by Italian province and exploit province-level variation in pardon totals for all prisoner releases occurring between 1962 and 1995. The authors find sizable impacts of prison on crime of an order of magnitude similar to the early incapacitation research in the U.S.

Buonanno and Raphael (2013), use relatively high-frequency crime and incarceration data at the national level as well as province-level variation to estimate the reverseincapacitation effects caused by the August 2006 Italian mass prisoner release. The authors find felony incapacitation effects on the order of 13 to 17 serious offenses per year served. However, the authors present several sets of results indicative of diminishing marginal 
incapacitation effects. First, they show that incapacitation effects are the largest for those inmates who replace the pardoned and/or those who are returned to prison the soonest after the mass release. In addition, the authors find much larger incapacitation effects in provinces with lower pre-pardon incarceration rates relative to provinces with higher pre-pardon incarceration rates. Both findings are consistent with great heterogeneity in offending behavior among those convicted and sent to prison and a decline in this propensity to offend among the incarcerated as the scale of incarceration increases.

Vollaard (2012) estimates incapacitation effects for repeat offenders exploiting a change in Dutch sentencing policy. The author analyzes the impact of a sentence enhancement in the Netherlands targeted at repeat offenders defined as those with over 10 prior felony convictions. In 2001, the Netherlands enacted an enhanced sentence of two years for such offenders, first allowing a small number of municipalities to experiment with the enhancement before nation-wide application in 2004. The author finds very large incapacitation effects, on the order of 50 to 60 reported thefts prevented per year of incarceration. However, the author also finds that those municipalities that dipped further into the repeat-offender pool in the application of the sentencing enhancement experienced significantly smaller crime reductions per additional prison-year served.

The findings from these European studies suggest that diminishing crime-abating returns may set in at relatively low incarceration rates. For both countries incapacitation effect estimate are comparable to or larger than estimates for the U.S. for data collected when the U.S. incarceration rate was comparable to that of Italy and the Netherlands. Most notably, this research finds incapacitation effects setting in quite quickly, with Buonanno and Raphael 
finding substantial declines in incapacitation effects at levels below 200 per 100,000 and Vollard finding declining marginal criminality even among offenders with 10 or more prior convictions. ${ }^{4}$

There are several studies of the crime-prison relationship based on U.S. panel data regressions. A key methodological hurdle that these studies must address concerns the likely simultaneous relationship between incarceration and crime. Specifically, while exogenous increases in the use of incarceration will incapacitate more people and perhaps provide a greater deterrent effect (creating a negative relationship between incarceration and crime), exogenous increases in crime for reasons unrelated to criminal justice policy will cause incarceration rates and crime to positively covary. Failing to account for the endogeneity of incarceration rates likely leads to crime-prison effects biased towards zero.

Levitt (1996) was the first to point out this identification problem and to propose a formal identification strategy. Using U.S. state panel data, Levitt exploits the fact that in years when states are under a court order to relieve prisoner overcrowding, state prison populations grow at relatively low rates. Using a series of variables measuring the status of prisoner overcrowding lawsuits as instruments for state level incarceration rates, Levitt finds 2SLS estimates of crime-prison elasticities that are considerably larger than comparable estimates from OLS with a corrected property crime-prison elasticity of- 0.3 and a violent crime-prison elasticity of -0.4 .

\footnotetext{
${ }^{4}$ The pre-2006 pardon Italian incarceration rate stood at roughly 100 per 100,000 (Buonanno and Raphael 2013). The Dutch incarceration rate in 2004 stood at roughly 124 per 100,000 (International Centre for Prison Studies, http://www.prisonstudies.org/info/worldbrief/, accessed on June 15, 2012). Note, these incarceration rates are inclusive of pre-trial populations and other inmates in the U.S. who would be serving sentenced for less serious crimes in local jails. Hence, these rates are generally lower than U.S. incarceration rates in the 1970 s and early 1980s.
} 
Johnson and Raphael (2012) use an instrument for incarceration based on the difference between a state's current incarceration rate and the state's steady-state incarceration rate implied by observable admissions and release rates. The authors derive an empirical prediction regarding the impact of this difference on next-year's change in incarceration based on a theoretical model of the relationship between crime and incarceration, and derive the conditions under which the transitory disparity between the actual and steady state incarceration rate provides a valid instrument for one-year lead changes in the actual incarceration rate. The authors analyze state level panel data for two time periods: 1978 to 1990 and 1991 to 2004 . The former period is characterized by a relatively low incarceration rate (186 per 100,000) while the latter period is characterized by a much a higher incarceration rate (396 per 100,000). For the early period, an additional prison year served is estimated to prevent roughly 2.5 felony violent offenses and 11.4 felony property offenses. Note, the total crimes prevented figure is quite close to the implied annual reverse incapacitation effects caused by the 2006 Italian pardon (Buonanno and Raphael 2013) and when expressed as elasticites, quite close to the estimates in Levitt (1996) using a much different identification strategy.

The estimates for the latter time period, however, are considerably smaller. The comparable figures for crimes prevented per prison year served for the period 1991 through 2004 are 0.3 violent felony offenses and 2.7 felony property offenses. Raphael and Stoll (2013) reproduce this analysis with updated data for three time periods: 1977 through 1988, 1989 through 1999, and 2000 through 2010, with corresponding weighted-average state incarceration rates of 171,349 , and 449 . This reanalysis find very small prison-crime effects for 
the latter two time periods, but fairly large effects for the earliest time period, strongly suggestive of diminishing returns to scale. Liedke, Piehl and Useem (2006) provide similar evidence with U.S. panel data.

Unlike the Dutch and Italian studies, the U.S. panel data estimates represent joint incapacitation/deterrence effects associated with increases in incarceration, estimates that in theory should be larger than the estimates of pure incapacitation effects. ${ }^{5}$ Nonetheless, for recent years, empirical estimate find very small crime-prevention effects of marginal increases in incarceration. Given the trajectory of U.S. incarceration rates over the past three decades, this research has been based largely on variation within and between states in the rate of positive incarceration growth. In what follows, we present results from analysis of a single state experiencing a very large and relatively sudden decline in incarceration rates.

\section{Description of California's Public Safety Realignment Reform and Our Empirical Strategy}

In April 2011, the state of California enacted broad correctional reform legislation under the banner of corrections realignment. The legislation eliminates the practice of returning parolees to state prison custody for technical parole violation for all but a small set of the most serious offenders. The legislation also defines a group of non-serious, non-sexual, non-violent

\footnotetext{
${ }^{5}$ Note, the Italian studies estimate the effect of mass releases absent any change in sentencing policy. The 2006 pardon, however, included the provision that any pardoned inmate convicted of a further crime would have the remaining unserved sentence tacked on to their new sentence. Hence, for those pardoned the reverse incapacitation effect was likely offset by an increase in general deterrence. Drago et al. (2009) present evidence regarding the pure deterrent effect associated with this threat of a longer prison sentence. The authors exploit the fact that among pardoned inmates with similar offenses and sentences, those who are admitted to prison closer to the date of the pardon faced a larger post-release sentence enhancement than those who are admitted to prison at earlier dates. The authors demonstrate statistically significant and substantially higher recidivism rates among those pardoned inmates facing lower effective sentence enhancement. Nonetheless, the analysis in Buonanno and Raphael (2013) suggest that this deterrent effect is small relative to the impact on crime operating through incapacitation.
} 
offenders who upon conviction will serve their sentences in county jails. These offenders earn good-time credits at faster rates than they would within the state prison system and can be given split sentences that involve alternative monitoring within the community. More generally, judges are now afforded greater discretion to devise alternatives to confinement in the sentencing of these offenders.

The legislation was prompted by pressure from a federal three-judge court overseeing the California prison system, impanelled as a result of legal decisions in two lawsuits against the state filed on behalf of California prison inmates. In one (Coleman v. Brown), it was alleged that California was providing inadequate health care services to its prison population. In the other (Plata v. Brown) it was alleged that the system was providing inadequate mental health services. Both resulted in rulings in favor of the plaintiffs finding that prison overcrowding was the primary cause of the inadequate services and that the poor health and mental health care systems violated the $8^{\text {th }}$ amendment prohibition against cruel and unusual punishment. Assembly Bill 109 (referred to in the state as "corrections realignment") was passed and implemented under threat of a federal court order to release up to 35,000 inmates if the state failed to act on its own.

The effect of these reforms on the California prison population did not occur as suddenly as was observed for the 2006 Italian collective pardon. However, realignment did result in a relatively quick reduction in the California prison population larger in magnitude on both a population adjusted and unadjusted basis. ${ }^{6}$ This reduction was largely effected through

\footnotetext{
${ }^{6}$ The 2006 Italian release amounted to a roughly 21,000 person reduction against a national population of roughly $58,000,000$. Between September 2011 and December 2012, California's prison population declined by 27,541
} 
a reduction in prison admissions. Figure 1 presents weekly admissions to the California state prison system from October 2010 through May 2013. Through September 2011, weekly admissions oscillate around 2,200. With the implementation of realignment, admissions drop discretely and permanently to roughly 600 per week. Figure 2 present comparable figures for weekly releases from California state prisons. Prior to realignment's implementation, admissions and releases are in rough balance. Following the policy reform, releases fall as well, yet more slowly than the drop in admissions. Ultimately, releases fall to the comparable level of admissions. The slower drop effectively created a period where admissions fell far short of releases, causing the overall prison population to decline.

Figure 3 shows the impact of these changes in flows on the total prison population (measured at the end of each month). The figure reveals a clear drop in the state's prison population, with a total decline between September 2011 and May 2013 of 27,846. The effect of realignment was felt immediately, with 12 percent of the decline occurring within one month of implementation, 46 percent within three months, 70 percent within five months, and 82 percent within seven months. By October of 2012, roughly one year following the legislation's implementation, the prison population stabilizes. Expressed per 100,000 California residents, the prison incarceration rate declined from 426 to 348 . The state's current incarceration rate is the lowest incarceration rate experienced since 1991 (a date that pre-dates the passage of California's "Three Strikes" ballot amendment).

inmates with nearly 80 percent of this decline occurring during the first six months following the implementation of the reform. California's population as of July 2012 is $38,041,430$. 
Despite operating under a common state penal code, California counties vary considerably in their use of the state prison system. ${ }^{7}$ Not surprisingly, this variance in prerealignment incarceration rates naturally led to large cross county differences in the impact of realignment. Figure 4 documents this fact. The figure presents a scatter plot of the change in county-specific incarceration rates between September 2011 and September 2012 (roughly the first year of realignment) against the county's incarceration rate in June 2011. The variation in both starting incarceration rates as well as the change in incarceration rate is quite remarkable. Regarding pre-realignment incarceration rates, these rates vary from below 200 per 100,000 to over 1,000 per 100,000. Naturally, counties with lower incarceration rates to begin with experienced much smaller declines in their prison incarceration rates as a result of the reform. The changes in county-specific incarceration rates range from slight pre-post realignment increases to declines of over 160 inmates per 100,000 residents. Hence, among the counties experiencing the largest impacts, the per-capita magnitude of the decline would be roughly equivalent (if not larger than) eliminating the prison populations of many Western European countries.

Since our identification strategy exploits the inter-county variation displayed on the vertical axis of Figure 4, we should document the pre-reform differences between highincarceration and low-incarceration counties. Table 1 presents some basic descriptive statistics

\footnotetext{
${ }^{7}$ Inmates are admitted through the county courts to the state prison system. Those convicted are adjudicated in the county where the crime was committed. In most instances, this is also the county of resident of the offender. Upon release, inmates are returned to their county of commitment under several alternative conditional release programs. When county of commitment differs from county of last residence, inmates are often transferred from the commitment county to the county of last residence to complete their parole or post-release community supervision terms. Hence, changes in prison incarceration rates at the county level generally gauge changes in the extent to which counties are incarcerating their local residents in the state system. Note, county residents are usually housed in institutions outside of the county, with location determined by the individual's security classification and bed availability.
} 
for counties stratified into thirds according to pre-realignment prison incarceration rates. The differences in the average number of county residents in a state prison per 100,000 county residents across these three categories is striking, with average rates of 234,402 , and 612 for counties in the bottom, middle, and top thirds of the distribution, respectively. Moreover, these counties differ along several other notable dimensions. Poverty rates increase uniformly as we move from low- to high-incarceration rates counties. Moreover, counties with relatively high incarceration rates also have relatively high pre-realignment violent and property crime rates. ${ }^{8}$

We also find some evidence that public opinion in high-incarceration rate counties tends to be relatively less supportive of sentencing reforms targeted at moderating punishment for criminal offenders, suggesting potential important ideological differences across counties. Specifically, the table shows the average proportion of county voters that support the 2012 California state proposition 36, a proposed amendment that essentially scales back the scope of California's three-strikes law. Support for proposition 36 is notably lower in high incarceration rate counties, with average values of $70.2,65.2$, and 62.4 percent in the bottom, middle, and top third counties, respectively. A similar pattern also emerges when we substitute voter support for the 2012 state proportion 34, a failed effort to eliminate the death penalty.

Table 2 presents results from a simple linear regression of pre-reform county incarceration rates on pre-reform poverty rates, the proportion of county residents supporting Proposition 36, and the pre-reform violent and property crime rates. Both poverty as well as criminal justice ideology exhibit significant partial correlations with pre-reform incarceration rates. Interestingly, after accounting for these two factors there is no partial correlation

\footnotetext{
${ }^{8}$ Technically, the last three months of 2011 are in the post-realignment period. Thus the annual crime rates in Table 1 span the reform though mostly reflect crime that predates the reform's implementation.
} 
between crime and incarceration. The table also illustrates the magnitude of the coefficient estimates by calculating the implied effect of a variation in the explanatory variable equal to its interquartile difference. The implied effects suggest that both crime fundamentals (as gauged by poverty) as well as ideology (as gauged by support for proposition 36) were important independent determinants of county incarceration rates prior to the reform.

Our principal estimation strategy exploits this cross-county variation in the impact of realignment. Specifically, we assess whether counties that have experienced larger declines in county-specific prison incarceration rates experience relatively large increases in crime rates. This analysis relies on estimation of various specification of the regression

$$
\Delta \text { Crime }_{i t}=\alpha_{i}+\beta_{t}+\delta \Delta \text { Pr ison Incarceration } \text { Rate }_{i t}+\gamma \Delta \text { Jail Incarceration Rate }{ }_{i t}+\varepsilon_{i t},
$$

where $i=(1, \ldots, 57)$ indexes counties, $t=($ Oct 2011,...,Sep 2012) indexes the end month of the change, $\Delta$ Crime $_{i t}$ is the pre-post realignment change in monthly crime rates, $\Delta$ Prison Incarceration Rate it $_{\text {is }}$ the pre-post realignment change in the number of county residents incarcerated in a state prison, $\Delta$ Jail Incarceration Rate $_{i t}$ is the pre-post realignment change in the number of county residents incarcerated in a local county jail, $\alpha_{\mathrm{i}}$ and $\beta_{\mathrm{t}}$ are county and month fixed effects respectively, $\delta$ and $\gamma$ are parameters to be estimated, and $\varepsilon_{i t}$ is a mean-zero error term. Before discussing how we characterize the pre-realignment change, we offer some general comments about the specification of equation (1) and the variation used to identify the key coefficient of interest, $\gamma$. 
First, the reform explicitly provides for the incarceration of non-violent, non-sexual, and non-serious offenders in local jails as well as for discretion for local criminal justice officials to punish released prison inmates who violate the terms of their conditional releases with jail spells. In practice, this has led to the reduction in the prison population being partially offset by an increase in the population of county jails. Figure 5 illustrates this fact. The state's total jail population was roughly 72,000 in the months prior to realignment and then gradually increased to over 80,000 over the first post-reform year. Lofstrom and Raphael (2013) find a crossinstitution substitution rate of about one for three -- that is to say, each three person reduction in a county's prison incarceration rate resulted on average in a one person increase in the local jail incarceration rate. Moreover, most of this increase reflected increases in the number of convicted felons serving time in local jails, rather than an increase in jail incarceration for parole violators. Ultimately we wish to answer whether an increase in the number of convicted offender not in custody (i.e., on the street) impacts crime. Hence, it is vital that we control for the corresponding changes in jail incarceration rates in equation (1).

Second, equation (1) includes a complete set of month fixed effect corresponding to the end month of the change defining each observation. Including time fixed effects effectively nets out the overall state time trends for crime changes and identifies the prison-crime effects based on variation above and beyond what occurs for the state overall. This is a particular important adjustment, as preliminary crime data published by the $\mathrm{FBI}$ for 2012 suggests that among Western states (and in particular, states that share a border with California), crime increased in 2012. 
Third, equation (1) includes a complete set of county fixed effects. Counties in California, and cities within the counties, vary considerably with regard to demographics, economic conditions, and local fiscal conditions. Most notably, several California cities vary in terms of their law enforcement staffing levels as well as changes in staffing levels over the time period we study here. By adding county fixed effects, we adjust for general trends in changes and identify the prison-crime effect based on within-county variation above and beyond county overall averages for the dependent and explanatory variables.

Our characterization of the change in the dependent and explanatory variables merits a detailed discussion. Absent a policy-induced shock to the prison population, such as the implementation of realignment, one might expect prison incarceration and crime rates to positively covary. For example, higher crime, leads to more arrest, which leads to a larger jail population of inmates awaiting trial and transfer to prison, which in turn leads to a large prison population. The reform in question, however, should identify the causal link running from prison to crime rates, as the legislation and prison reduction is driven by a policy reform that in turn, is driven by forces having nothing to do with state crime trends. Hence, our analysis must focus on isolating variation in the prison population that is attributable to the reforms ushered in by $\mathrm{AB} 109$.

One possible manner of characterizing the change in crime and incarceration rates would be to calculate the changes for a given post-realignment month relative to the comparable month a year previous. While we have data through December 2012, September 2012 is the last month for which the base month of the change would still lie within the prereform period. Focusing on the change relative to one year previous ensures that we are 
making comparisons relative to the same time last year, and that any association we observe between the prison incarceration rate and crime is not being driven by particular effects of calendar month and potential heterogeneity in these effects across counties. Moreover, focusing on pre-post realignment changes ensures that variation in the incarceration rate is primarily driven by the policy reform. Hence, our first strategy is to analyze the relationship between the change in county crime rates and county prison incarceration rates using the change in monthly rates for October 2011 through September 2012 relative to monthly crime rates one year previous.

A potential weakness of this strategy is that the change over the course of a full year may reflect underlying trends in crime and corrections that pre-date the implementation of realignment. This is particularly problematic for the earlier months in our analysis, such as October through December 2011 when the majority of the period over which changes are measured lie within the pre-realignment period. Variation in crime and incarceration over this earlier time period may be driven by exogenous shocks to criminal offending that create the simultaneity bias to which much research on the prison-crime effect has been devoted to correcting. In addition, several policy reforms in California predate AB109, most of which were geared towards reducing the prison population to comply with the federal court order. For example, in January 2010 California implemented probation reform, with the primary change being the implementation of performance incentive funding that granted local probation departments 40 to 45 percent of state corrections savings for reducing admissions to prison from the stock of convicted offenders on probation. In addition, in late 2009 the state implemented a reform to state parole, officially creating a new class of low-risk prison releases 
for less intensive post-release supervision. Combined, these two reforms reduced the prison population between January 2010 and September 2011 from 167,694 to 160,482. Given the policy activity prior to realignment's implementation and other potential sources of variation in crime and incarceration rates, one might want to focus more tightly on time periods that isolate variation in incarceration rates, and consequent impacts on crime, more clearly driven by the 2011 reforms.

As an alternative, we also characterize the changes in crime and incarceration rates focusing on the more narrow time windows using the pre-post changes in monthly crime and incarceration rates relative to September 2011. Of course, focusing on changes relative to a single month introduces a new measurement problem. Namely, changes between September in one year and all subsequent calendar months from October through September of the following year may introduce bias associated with cross-county variation in the seasonality of crime. For example, tourist visits to San Francisco and Southern California beaches increase during the summer, a factor likely increases crime rates. On the other hand, tourist visits to desert cities such as Palm Springs decline greatly during summer months, as does time out of doors among local residents due to the extreme heat. Hence, one might expect different monthly patterns in crime across California counties.

To address this issue, we modify our tightly focused change calculations to account for underlying seasonal variation in crime specific to counties. Specifically, we calculate the prepost realignment changes in incarceration and crime rates relative to September 2011 net of the comparable change in crime one year earlier. For example, our pre-post change ending in say April 2012 is calculate by first measuring the difference in crime and incarceration rates 
between April 2012 and September 2011 for each county, then calculating comparable differences for the period from September 2010 and April 2011, and then subtracting the latter change from the former. We refer to this characterization of the dependent and explanatory variables as our difference-in-difference specification.

In the presentation of our empirical results, we estimate various specifications of Equation (1) using both characterizations (the year-over-year changes and the difference-indifference changes) of the dependent and explanatory variables. We test for the sensitivity of our results to inclusion of the month and county fixed effects and the inclusion of the jail incarceration variable. Finally, all models estimation results presented below calculate robust standard errors that permit clustering by county.

\section{Data Description and Basic Crime Trends}

The data for this project come from several sources. Crime data are provided by the California Criminal Justice Statistics Center (CJSC) within the Office of the California State Attorney General. Crime totals for part 1 felony offenses are reported by month and police agency. The data include county identifiers that permit summing total offenses by county and month. These data are publicly available for the period 2003 through 2012 . We use data for 2010 through 2012 for this project. ${ }^{9}$

Monthly data on county jail populations come from the California Jail Profile Survey, administered and maintained by the California Board of State and Community Corrections. To calculate jail incarceration rates, we use average daily population figures for each county and

\footnotetext{
${ }^{9}$ Note, these data are eventually released by the FBI in the Uniform Crime Report Series.
} 
each month. While there are 58 counties, one small rural county (Alpine) in Northern California does not maintain its own jail system. Hence, nearly all of our analyses (with the exception of the aggregate trends presented shortly and our synthetic cohort analysis to follow) focus on the 57 counties with independent jail systems.

The California Department of Corrections and Rehabilitation (CDCR) calculates prison totals by county of commitment only intermittently and hence does not publish the monthly totals we need to implement our estimation strategy. However, CDCR has provided us with weekly admissions and releases to the system by county and by controlling offense for the period ranging from October 2010 through May of 2013. The difference between cumulative admissions and releases between any two dates for a given county provides the change in the incarceration total. We use this strategy to tabulate the change in incarceration by county between any two months, using the latest date within each month as the starting and end points. To convert to rates, we normalize by the average of the county population estimates for the two calendar years straddled by the change.

Before presenting our formal estimation results, we first present some basic descriptive statistics describing recent crime trends in the state. Table 3 presents annual crime rates for 2010, 2011, and 2012. The table provides rates for overall violent and property crime as well as for each of the specific crimes that constitute these broader crime categories. Between 2010 and 2011, all crime rates decline, with fairly large percentage declines in overall violent crime and a more modest decline in property crime. From 2011 to 2012, crime rates increase uniformly, with relatively small increases in violent crime but more pronounced increases in property crime. The overall violent crime rate increases by 2.5 percent while the overall 
property crime rate increases by 6.6 percent. We observe the largest percentage increase in motor vehicle theft (13.5 percent). Comparing 2012 crime rates to 2010 crime rates, violent crime in 2012 is generally lower than violent crime in 2010, though murder rates are slightly higher. Property crime rates, however, are uniformly higher with the percentage difference relative to 2010 greatest for auto theft (8.5 percent).

Figure 6 and 7 display monthly total crime for January 2010 through December 2012, a comparison that permits a tighter visual depiction of the timing of the reform. For reference, the figures include two vertical lines marking the beginning of each calendar year and a thick vertical line marking the last pre-reform month (September 2011). Figure 6 does not reveal any visible increase in violent crime with the timing of realignment's implementation, though the annual monthly violent crime totals in 2012 appear slightly elevated relative to comparable months in 2011. Nonetheless, a comparison across all three years reveals no visible departures in 2012.

On the other hand, Figure 7 reveals a gradual and sustained increase in total property crimes following the reform. During the pre-reform period, monthly property crime totals oscillate around 80,000 incidences per month. Following realignment, monthly incidents drift upwards towards to 90,000 incidents per month.

Finally Figure 8 visibly depicts the cross-county relationship between changes in crime rates and changes in prison incarceration rates. For our two alternative characterizations of the changes in incarceration and crime (the year-over-year changes in monthly crime and our difference-in-difference measure), the figure presents scatter plots of the crime changes against the incarceration changes for each of the 57 counties and for each of the twelve post- 
reform months in our analysis period. The scatter plots are weighted by county population and include a line depicted a population-weighted bivariate regression between the two variables. Figures $A$ and $B$ depict the change in violent crime rates against the change in incarceration rates. Despite very large changes in incarceration rates, we observe little evidence of relative increases in violent crime. The fitted regression for the year-over-year change exhibits a modest negative slope, while the regression line using the difference-in-difference characterization has slope that is basically zero. The scatter plots for property crime rates exhibit more evidence of a negative slope.

\section{Cross-County Empirical Results}

Table 4 presents estimations results for various specifications of equation (1). Panel A presents results where the dependent variable is the change in the total violent crime rate while panel $B$ presents results for the change in the total property crime rate. Within each panel, we present results for each of our characterizations of the pre-post change in the dependent and explanatory variables. Within each characterization, we present results for five specifications, varying whether we control for the contemporaneous change in the local jail population and the mix of county and month fixed effects. The final specification corresponds to the full model specified in Equation (1). All regressions are weighted by county population and the calculated standard errors are clustered by county.

Beginning with the results for violent crime, the year-over-year change models yields some evidence of an adverse effect of the decline in the prison population on crime rates. Adjusting for the change in the jail population but not controlling for month or county fixed 
effects yields a statistically significant estimate of 0.034 violent crimes per 100,000 prevented per month for each one person increase in the prison incarceration rate. This estimate however is quite sensitive to adjusting for month fixed effects, with the magnitude of the effect dropping by nearly half when month effects are added to the specification. The model controlling for county fixed effects only yields a slightly higher and significant estimate of 0.04 crimes prevented per 100,000 . The final specification controlling for both month and county fixed effects yields a positive statistically-insignificant coefficient.

The models employing the difference-in-difference characterization yield weaker evidence of an impact of variation in county incarceration rates on county violent crime rates. In several specifications, the coefficients are the wrong sign and in four of the five specifications are statistically insignificant. The one specification where the coefficient has the correct sign and is significant is when we control for county fixed effects only and the change in the local jail incarceration rate. However, adding month effects to the specification, essentially adjusting for state-level trends, reduces the coefficient to zero.

The results for property crime reveal more consistent evidence of a prison-crime effect. Beginning with the year-over-year models, the coefficient estimates in all five specification are roughly consistent with one another (ranging from -0.089 to -0.164 ) and statistically significant in four of the five specifications. Controlling for month effects does attenuate the coefficient somewhat, suggesting that part of the relationship in the unadjusted data reflect broader forces influencing the entire state. The difference-in-difference models yields slightly higher estimates (ranging from -0.091 to -0.183 ) and are all statistically significant with the exception of the results from the full specification. 
The magnitudes of these results are consistent with those from previous research on the prison-crime effects. For example, Johnson and Raphael's (2012) analysis of state-level panel data provides estimates the effect of a one-person increase in the prison incarceration rate for the period 1978 to 1990 and 1991 and 2004. During the early period, state incarceration rates averaged 186 per 100,000, while during the latter period state incarceration rates averaged 396 per 100,000. For the early period, the authors find that each prison year served reduced annual reported property crimes by 11.4 incidents and annual violent crimes by 2.5 incidents. During the latter period, each prison year served reduced annual reported property crime by 2.6 incidents and annual reported violent crime by 0.4 incidents. Raphael and Stoll (2013) update these results for the more recent period from 2000 to 2010 when the average state incarceration rate was 449 per 100,000. They estimate that each prison year served prevented 2.05 reported property crimes per year and 0.18 reported violent crimes.

To render the results in Table 4 comparable, we must multiply each coefficient by 12 since the estimation results here pertain to monthly crime. The largest point estimate in Panel A for violent crime suggests that each prison month served prevents 0.041 violent incidents per month (the specification from the difference-in-difference models controlling for the change in the jail incarceration rate and county fixed effects). This coefficient estimate implies that each prison year served prevent 0.5 violent incidents. For property crime, the largest coefficient comes from the difference-in-difference model adjusting for the change in the jail population and not controlling for month or county fixed effects (with a coefficient on the change in the prison incarceration rate of -0.183 ). This estimate implies that 2.2 reported property crimes per year are prevented per prison year served. Note, both estimates are likely too high as we have 
selectively chosen the largest coefficients from the table, neither of which are adjusted for state level crime trends. Nonetheless, the implied effect sizes are consistent with those from previous research and suggest impact per prison year served that are considerably lower than estimate from time periods in the U.S. when the incarceration rate was much lower.

Table 5 presents comparable estimation results for individual violent crimes. We present results for the same set of model specifications reported in Table 4. Here, however, we only report coefficient on the change in the incarceration rate to conserve space. For murder and rape, we find no evidence of an effect of realignment-induced declines in incarceration on these crimes. There isn't a single negative and statistically significant coefficient in any of the specifications. For robbery we find some evidence of small adverse effect in some specifications. However, the robbery coefficient never survive controlling for month fixed effects, suggesting that factors influencing crime statewide explain these negative coefficients in the more parsimoniously-specified models. We do find more consistent evidence of relative increases in aggravated assault rates in counties experiencing relatively large reductions in incarceration rates in the year-over-year change models. The difference-in-difference models however, generally find no effect of realignment on aggravated assault. ${ }^{10}$

Table 6 presents comparable results for individual property crime rates. For burglary and larceny, results are inconsistent across specifications and across our alternative characterization of pre-post reform change. Surprisingly, the evidence of an effect of the reform on larceny theft is the weakest. Note, increase in larceny theft accounts for nearly 50

\footnotetext{
${ }^{10}$ We suspect that the evidence we do see for aggravated assault may be driven by that larger county jail populations and the anecdotal evidence that aggravated assaults occurring in county jails are more likely to be recorded as official criminal incidents relative to aggravated assaults that occur in state prisons. As we cannot distinguish aggravate assaults occurring within institutions form aggravated assaults occurring among the noninstitutionalized, we cannot evaluate this conjecture.
} 
percent of the increase in property crime rates between 2011 and 2012 for the state, suggesting that the recent prison reforms provides only a partial explanation for the increase in property crime statewide. In contrast, we find robust evidence that realignment-induced declines in the prison population have caused increases in motor vehicle theft. For both change characterizations, the coefficients estimates are statistically significant in each specification, do not appear to be sensitive to controlling for month effects and are comparable in magnitude across specifications. Interestingly, the largest point estimates come from the complete model specifications inclusive of county and year fixed effects. The complete model results suggest, each prison year served prevents roughly 1.2 motor vehicle thefts.

To summarize, the cross county results suggest that at most each prison year served among those not incarcerated as a results of realignment prevent on average half of a violent felony offense and roughly 2 property offenses. Our complete model specifications that adjust for time trends and county specific factors suggest even smaller effects, with no impact on violent crime and an effect on property crime limited to auto theft of 1.2 incidents per year. These results are in line with prior research and suggest that the incapacitation/deterrence effects of incarceration in the U.S. are generally relatively low at high incarceration levels.

\section{Synthetic Cohort Analysis}

Thus far, we have relied on cross-county differences in the impact of realignment on county-specific prison incarceration rates to study the effects on crime. One might contend that focusing on the effects at the county level may be controlling away any change in general deterrence statewide associated with the change in the penal code (especially in the models 
that adjust for time fixed effects). While the great county-level heterogeneity in the application of the common penal code prior to realignment might call such concerns into question, it certainly is possible that the very public and high-publicity proceedings surrounding the reform may have altered expectations regarding punishment severity, and altered criminal behavior as a result. An additional concern involves the relatively small geographic units of analysis (counties) and the fact that in many urban areas, county borders are relatively arbitrary boundaries that do not demarcate meaningful social ecological divisions. To the extent that one county's realignment caseload spills over into another county's crime rate, our county-level regression analysis may under-estimate the effects of the reform on crime rates.

To complement our county-level analysis, here we present results using state-level crime data for California and the rest of the nation. Analyzing state-level data will minimize the bias associated with deterrence, as we are looking for an overall effect for the state in question. Moreover, California's major population centers do not cross state boundaries, and hence issues of spillover are less of a concern. Using data from the Federal Bureau of Investigation's Uniform Crime Report for the period 2000-2012, we employ the synthetic control approach of Abadie, Diamond and Hainmueller (2010) to identify a convex combination of states with prerealignment crime trends that closely match those of California. We then use this synthetic comparison group to chart out the counterfactual path for California in the absence of realignment and use this as a benchmark against which actual California crime trends can be compared.

To be specific, let the index $\mathrm{j}=(0,1, \ldots, \mathrm{J})$ denote states. The value $\mathrm{j}=0$ corresponds to California and $\mathrm{j}=(1, \ldots, \mathrm{J})$ correspond to each of the other $\mathrm{J}$ states that are candidate contributors 
to the control group (or in the language of Abadie et. al, the donor pool). Define $F_{0}$ as a $11 \times 1$ vector with elements equal to the offense specific crime rates in California in years 2000 through 2010 (the 11 years we use here as our pre-intervention period). Similarly, define the $11 \mathrm{xJ}$ matrix $F_{1}$ as the collection of comparable time series for each of the $\mathrm{J}$ states in the donor pool (with each column corresponding to a separate state-level time series for the period 2000 through 2010).

The synthetic control method identifies a convex combination of the $\mathrm{J}$ states in the donor pool that best approximates the pre-intervention time series for the treated state. Define the Jx1 weighting vector $W=\left(w_{1}, w_{2}, \ldots, w_{J}\right)^{\prime}$ such that $\sum_{j=1}^{J} w_{j}=1$, and $w_{j} \geq 0$ for $\mathbf{j}=(1, \ldots, J)$. The product $F_{1} W$ then gives a weighted average of the pre-intervention time series for all states omitting California, with the difference between California and this average given by $F_{0}-F_{1} W$. The synthetic control method essentially chooses a value for the weighting vector, $W$, that yields a synthetic comparison group (consisting of an average of some subset of donor states) that best approximates the pre-intervention path for California. Specifically, the weighting vector is chosen by solving the constrained quadratic minimization problem

$$
W^{*}=\underset{W}{\arg \min }\left(F_{0}-F_{1} W\right)^{\prime} V\left(F_{0}-F_{1} W\right)
$$

S.t.

$$
W^{\prime} i=1, w_{j} \geq 0, j=(1, \ldots J)
$$


where $V$ is a $11 \times 11$, diagonal positive-definite matrix with diagonal elements providing the relative weights for the contribution of the square of the elements in the vector $F_{0}-F_{1} W$ to the objective function being minimized.

Once an optimal weighting vector $W^{*}$ is chosen, both the pre-intervention path as well as the post-intervention values for the dependent variable in "synthetic California" can be tabulated by calculating the corresponding weighted average for each year using the donor states with positive weights. The post-intervention values for the synthetic control group serve as our counterfactual outcomes for California.

Our principal estimate of the impacts of realignment on crime uses the synthetic control group to calculate a simple difference-in-differences estimate. Specifically, define Outcome $e_{\text {pre }}^{C A}$ as the average value of the outcome of interest for California for the pre-intervention period 2000 through 2010 and Outcome $e_{\text {post }}^{C A}$ as the corresponding average for the only post-treatment year currently available in the UCR data, 2012. Define the similar averages Outcome $e_{\text {pre }}^{\text {Syth }}$ and Outcome $_{\text {post }}^{\text {Synt }}$ for the synthetic control group. Our difference-in-differences estimate subtracts the pre-intervention difference between the averages for California and synthetic California from the comparable post-intervention difference, or

$$
D D_{C A}=\left(\text { Outcome }_{\text {post }}^{C A}-\text { Outcome }_{\text {post }}^{\text {syth }}\right)-\left(\text { Outcome }_{\text {pre }}^{C A}-\text { Outcome }_{\text {pre }}^{\text {syth }}\right)
$$

To formally test the significance of any observed relative increase in California's crime rates, we apply the permutation test suggested by Abadie et. al. (2010) to the difference-in-difference 
estimator discussed above. ${ }^{11} \quad$ Specifically, for each state in the donor pool, we identify synthetic comparison groups based on the solution to the quadratic minimization problem. We then estimate the difference-in-difference for each state as if these states had enacted the equivalent of California's realignment with comparable timing. The distribution of these "placebo" difference-in-difference estimates then provides the equivalent of a sampling distribution for the estimate $D D_{C A}$. To be specific, if the cumulative density function of the complete set of $D D$ estimates is given by $F($.$) , the p-value from a one-tailed test of the$ hypothesis that $D D_{C A}<0$ is given by $F\left(D D_{C A}\right)$.

Notably, we do not include 2011 in the pre-realignment period. Recall, the last three month of 2011 are in the post period. Ideally, we would perform this analysis with monthly data using September 2011 as the final pre-treatment month. However, monthly data for the entire nation is not yet available. This will likely be the focus of future research.

Figure 9 presents violent crime rate trends for California and for our "synthetic California." The synthetic comparison estimator yields a very good match for violent crime rates in the pretreatment period, with little visible difference between California and its synthetic comparison group. Most notably, there is little evidence of a relative increase in violent crime in California in 2012. Figure 10 provides a comparable figure for property crime. Again, the pre-treatment crime trends for California and synthetic California are quite similar. Here however, we observe divergence in crime trends, with slightly higher crime in California in 2011 and a wider differential in 2012.

\footnotetext{
${ }^{11}$ Buchmueller, DiNardo and Valletta (2009) use a similar permutation test to that described here to test for an impact of Hawaii's employer-mandate to provide health insurance benefits to employees on benefits coverage, health care costs, wages and employment.
} 
Table 7 presents our formal estimates from this analysis for overall violent and property crime rates. ${ }^{12}$ The top half of the table provides the actual crime rates in each year of the analysis period for California and Synthetic California, as well as the difference within each year. The bottom half of the table presents our effect size estimates and the results from the placebo test for statistical significance. We calculate the difference-in-difference estimates using 2012 as the post-period and three different pre-periods: 2006 to 2010, 2008 to 2010, and 2010 alone. The last two rows present the rank of the California estimate in the placebo distribution as well as a P-value from a one-tail test of the significance of the California estimate.

While we observe relative increases in violent crime in California in each comparison, California's relative increase ranks at most $13^{\text {th }}$ in the placebo distribution, never yielding a $p$ value less than 0.25 . By contrast, the relative increase in property crime consistently scores among the top five estimates in the placebo distribution, yielding a marginally significant effect. The point estimates are generally insensitive to the chosen pre-intervention comparison period, though the comparisons relative to 2010 yield the smallest estimates.

Table 8 presents results for individual violent crimes. Similar to the findings from our crosscounty analysis, we find no evidence of a relative increase in murder rates or the rate of rape/sexual assault. While the point estimates for aggravated assault are positive, the California estimates rank ninth in the placebo distribution and are not statistically significant. There is some evidence of a significant increase (at the 10 percent level) in the robbery crime rate of approximately 7 incidents per 100,000 residents in two of the three comparisons.

\footnotetext{
${ }^{12}$ The weighting vector from the minimization problem in equation (2) for each crime trend is presented in appendix Table A1. In general, only a subset of states receive positive weights in each comparison.
} 
Finally, Table 8 presents results for individual property crimes. There is no evidence of a statistically-significant relative increase in burglary or larceny theft. However, the relative increase in motor vehicle theft is pronounces and the largest among the distribution of placebo estimates.

How do these results compare to our findings from the cross-county analysis? In general, the two sets of results are quite consistent with one another. We noted above that between September 2011 and September 2012 (roughly the first post-realignment year), the California incarceration rate per 100,000 declined from 426 to 348, for a total decline of 78 per 100,000. Lofstrom and Raphael (2013) find that one of every three realigned inmates is re-incarcerated in county jails. Taking this into account would yield an increase in the number of former inmates "on the street" of roughly 51.5. The largest diff-in-diff estimate for motor vehicle theft (a relative increase of 110 incidents per 100,000) implies that each prison year served among this population prevents roughly 2.1 motor vehicle thefts. The smallest estimate implies that each prison year served prevents 1.4 incidents. These are somewhat larger than our estimate of the annual effect on auto thefts from the cross-county estimate of 1.24 , though generally within the ballpark of two property crimes per year served.

Regarding violent crime, we only find evidence in the synthetic comparison results of a positive effect on crime for robbery. The largest estimate is an increase in annual crime rates of roughly 7 incidents per 100,000 . This would amount to an average 0.14 incidents per year of street time among realigned offenders. Our largest point estimate for robbery from our crosscounty estimates implies an annualized effect of approximately 0.19. 


\section{Conclusion}

In our analysis, we find consistent evidence that the reductions in California's prison population caused by realignment increased property crime, especially motor vehicle thefts, but had little effect on violent crime. Results from cross-county analyses are roughly consistent with a synthetic-cohort analysis of aggregate state crime trends. Our estimates suggest that each prison year served among the population prevents roughly one to two property crimes per year and little to no violent crime.

Are these effects large? There are a number of ways to answer this question. First, we can compare our results to those from previous research. Not surprisingly given the magnitude of the quick and substantial drawdown in the California's prison population (of about 17 percent during the first year of realignment) there are no comparable single-state studies for the U.S. Our review of panel data research in the U.S. using different methods and different time periods of analysis suggest that the amount of crime prevented per prison year served during the 1970s and 1980s is many multiples the effects sizes that we document here. By contrast, more recent panel data research using post-1990 data finds effect sizes in line with our findings for California. Hence, relative to the effect sizes from times past, the estimated prison-crime effects here are small.

An alternative manner of characterizing these results would be to ask whether the returns in terms of crimes prevented outweigh the budgetary, or better yet, the complete social costs of incarcerating these marginal offenders. Heaton (2010) provides a summary of the findings from research on the costs of crime. With our estimates of the effect of realignment on crime, estimates of the costs of crime summarized in Heaton (2010), and estimates of the costs of 
incarceration in California, we can perform an analysis of the returns on the state's incarceration investment. Our preferred empirical results suggest that each prison year served prevents 1.2 auto thefts. Heaton's summary implies that each auto theft costs on average \$9,533 (in 2013 dollars). This suggests that each prison year served for those who as a result of realignment are no longer incarcerated prevents $\$ 11,783$ in crime related costs. The California Legislative Analyst's Office estimates that the annual cost of incarcerating a prison inmate in California is $\$ 51,889$. This suggests a return of 23 cents on the dollar. Incorporating some of the more difficult to price social costs in the calculation would certainly lower the return even further.

If we apply the slightly higher estimate that we obtain from the comparison of California's crime trend to a matched group of states, the return is somewhat higher. We noted in our analysis that we find no robust evidence of an effect of realignment on violent crime. We do however find some evidence that robbery crime may have increased due to the policy change (by about 5.9 more robberies per 100,000 residents). Incorporating these robbery estimates generates a return of about 45 cents in terms of crime prevention for each dollar spent on prison incarceration. Hence, the benefits in terms of prison expenditure savings outweigh the costs in terms of somewhat higher property crimes and this holds true even if we account for the possible increase in robberies resulting from realignment.

The simple cost-benefit analysis discussed above is useful for thinking about whether on the margin the social expenditures we are making are justified. However, such analysis considers the effectiveness of a particular policy intervention in isolation, without considering what could be achieved by reallocating the saved resources towards other uses. For example, it may be the case that a reduction in incarceration absent some other policy intervention may generate small 
increases in property crime. However, if the money saved from reduced prison expenditures was channeled into alternative and perhaps more cost-effective crime control strategies, increases in crime need not be the end-result. Moreover, to the extent that alternative crime-control tools are at least as effective as incarceration, maintaining low crime rates would not require additional public expenditures.

In characterizing the magnitude of our results, we could ask whether there are other interventions that generate a higher return per dollar spent. Perhaps the most obvious policy tool with the strongest research base regarding impacts on crime concerns the expansion of local police forces. There is considerable empirical evidence of the general effectiveness of higher police staffing levels on crime (Chalfin and McCrary 2012; DiTella and Shargraodsky 2004, Evans and Owens 2007 and Corman and Mocan 2000). These studies consistently find relatively large effects of expanding city police forces on local crime rates. Perhaps the most rigorous analysis of the effects of additional police on crime is provided in a recent study by Chalfin and McCrary (2013). In an analysis of the period 1960 through 2010 of medium to large U.S. cities, the authors find substantial and sizable effects of hiring additional police officers on crime rates, with notably statistically significant effects on very serious violent crimes. The empirical results in their analysis imply that each additional police officer reduces annual crime by 1.3 violent crimes and 4.2 property crimes. In an analysis of the costs and benefits of police expansion, the authors conclude that each dollar invested in additional policing generates $\$ 1.6$ in crime savings.

Of course, we have discussed only one possible alternative intervention (higher police staffing), but many alternative policy tools could and should be explored by researchers and policymakers. Such alternatives that may pay immediate returns include alternative systems of 
managing probationers and parolees, including swift-and-certain yet moderate alternative sanctions systems such as Hawaii's HOPE intervention, or high quality cognitive-behavioral therapy interventions for adult offenders. Interventions that may take a few years to bear fruit yet ultimately results in less crime and fewer offenders include early childhood human capital interventions and targeted interventions for high-risk youth. 


\section{References}

Abadie, Alberto; Diamond, Alexis and Jens Hainmueller (2010). "Synthetic Control Methods for Comparative Case Studies: Estimating the Effect of California's Tobacco Control Program," Journal of the American Statistical Association, 105(490): 493-505

Barbarino, Alessandro and Giovanni Mastrobuoni (2012), "The Incapacitation Effect of Incarceration: Evidence from Several Italian Collective Pardons," Working Paper.

Buchmueller, Thomas C, DiNardo, John and Robert G. Valleta (2009). "The Effect of An Employer Health Insurance Mandate on Health Insurance Coverage and the Demand for Labor: Evidence from Hawaii," Federal Reserve Bank of San Francisco Working Paper \#2009-08.

Buonanno, Paolo and Steven Raphael (2013), "Incarceration and Incapacitation: Evidence from the 2006 Italian Collective Pardon," forthcoming, American Economic Review.

Carson, E. Ann and Daniela Golinelli (2013), Prisoners in 2012 - Advance Counts, Bureau of Justice Statistics, U.S. Department of Justice, NCJ 242467.

Chalfin, Aaron and Justin McCrary (2012), "The Effect of Police on Crime: New Evidence from U.S. Cities, 1960-2010," NBER Working Paper No. 18815.

Chalfin, Aaron and Justin McCrary (2013), "Are U.S. Cities Under-Policed? Theory and Evidence." Working Paper, UC Berkeley.

Corman, Hope and H. NaciMocan (2000), "A Time-Series Analysis of Crime, Deterrence, and Drug Abuse in New York City," American Economic Review, 90(3): 584-604.

Di Tella, Rafael and Ernesto Schargrodsky (2004), “Do Police Reduce Crime? Estimates Using the Allocation of Police Forces after a Terrorist Attack," American Economic Review, 94(1): 115-133.

Drago, Francesco; Galbiati, Roberto and Pietro Vertova (2009), "The Deterrent Effects of Prison: Evidence from a Natural Experiment," Journal of Political Economy, 117(2): 257-280.

Evans, William N. and Emily G. Owens (2007), "COPS and Crime," Journal of Public Economics, 91(2): 181-201.

Heaton, Paul (2010), "Hidden in Plain Sight: What Cost-of-Crime Research Can Tell Us About Investing in Police", RAND.

Jacobson, Michael (2005), Downsizing Prisons: How to Reduce Crime and End Mass Incarceration, New York University Press: New York, NY. 
Johnson, Rucker and Steven Raphael (2012), "How Much Crime Reduction Does the Marginal Prisoner Buy?"Journal of Law and Economics, 55(2): 275-310.

Levitt, Steven D. (1996), "The Effect of Prison Population Size on Crime Rates: Evidence from Prison Overcrowding Legislation," Quarterly Journal of Economics, 111(2): 319-351.

Liedke, Raymond; Piehl, Anne Morrison and Bert Useem (2006), "The Crime Control Effect of Incarceration: Does Scale Matter?" Criminology and Public Policy, 5: 245-275.

Lofstrom, Magnus and Steven Raphael (2013), Impact of Realignment on County Jail Populations, Public Policy Institute of California, San Francisco, CA.

Marvell, Thomas and Carlysle Moody (1994), "Prison Population Growth and Crime Reduction," Journal of Quantitative Criminology, 10: 109-140.

Mauer, Mark (2006), The Race to Incarcerate, The New Press: New York, NY.

Owens, Emily (2009), "More Time, Less Crime? Estimating the Incapacitative Effects of Sentence Enhancements," Journal of Law and Economics, 52(3): 551-579.

Raphael, Steven and Michael A. Stoll (2013), Why Are So Many Americans in Prison? Russell Sage Foundation: New York, NY.

Spelman, William (1994), Criminal Incapacitation, Plenum Press: New York.

Spelman, William (2000), “What Recent Studies Do (and Don't) Tell Us About Imprisonment and Crime," in Michael Tonry (ed.) Crime and Justice: A Review of the Research,University of Chicago Press: Chicago, 27: 419-494

Vollaard, Ben (2012), "Preventing crime through selective incapacitation," Economic Journal, forthcoming.

Western, Bruce (2006), Punishment and Inequality in America, Russell Sage Foundation: New York, NY. 
Figure 1: Weekly Admissions to California State Prisons, October 2010 through May 2013

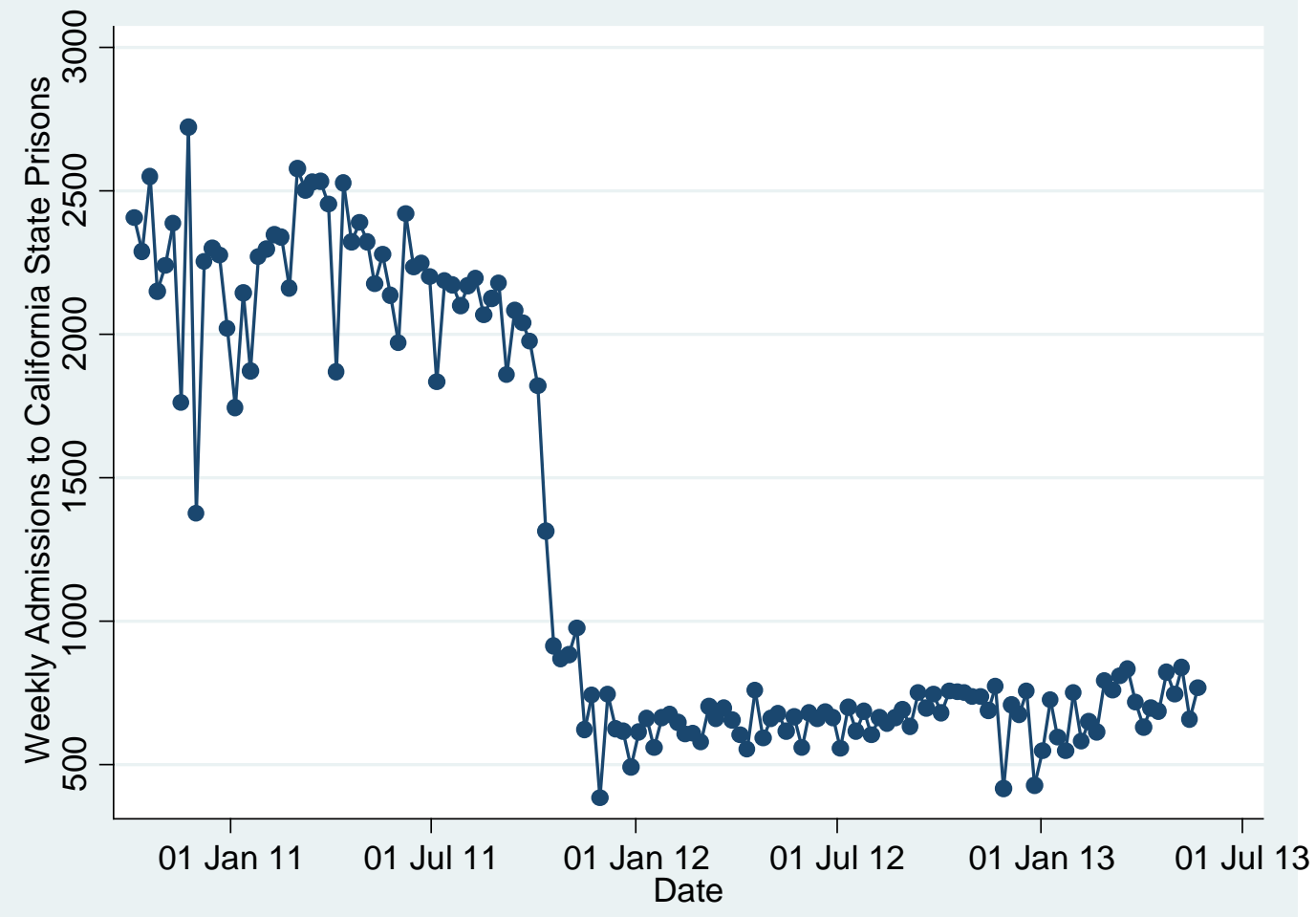

Figure 2: Weekly Releases from California State Prisons, October 2010 through May 2013

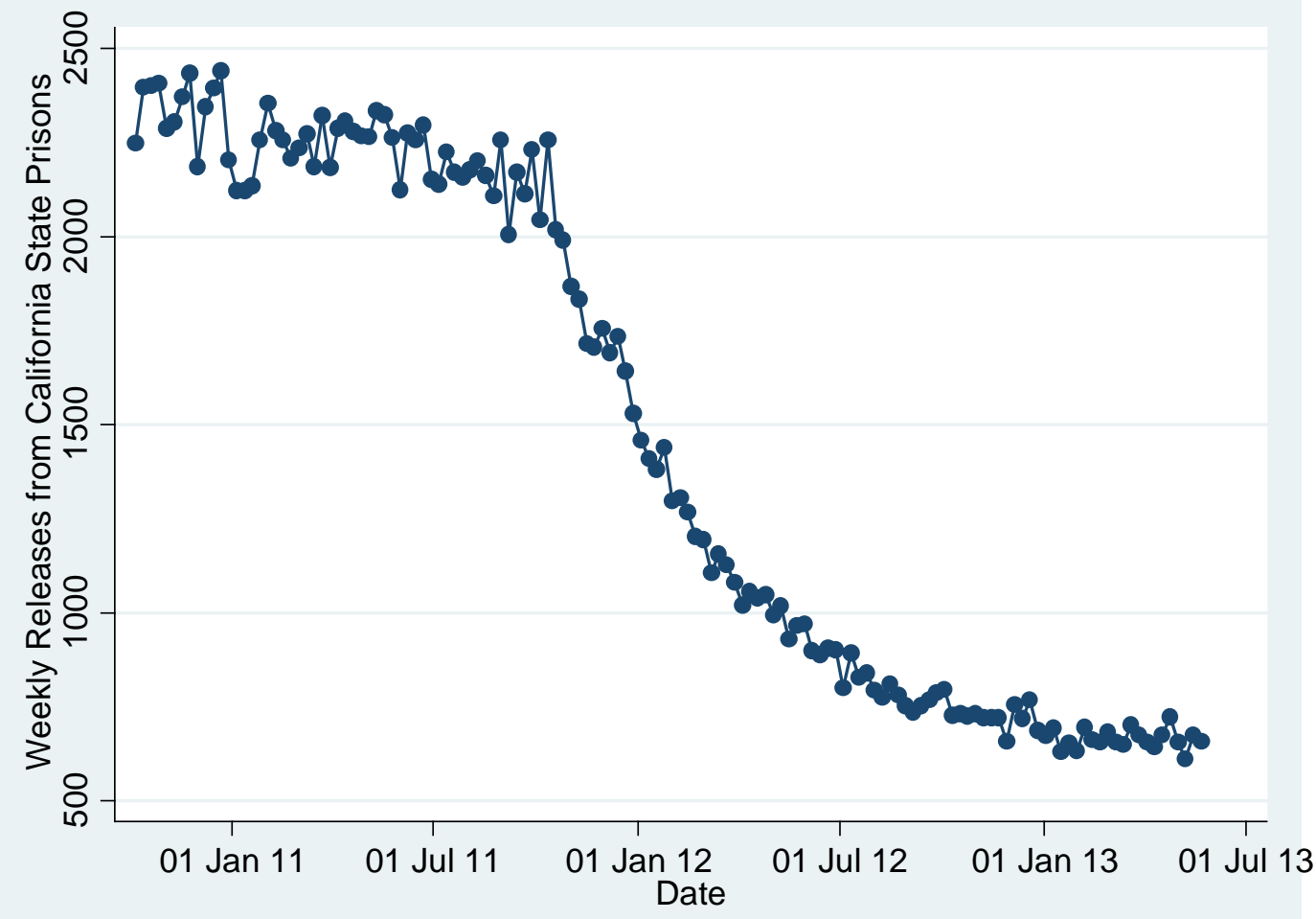


Figure 3: California Prison Population at the End of Each Month, October 2010 through May 2013

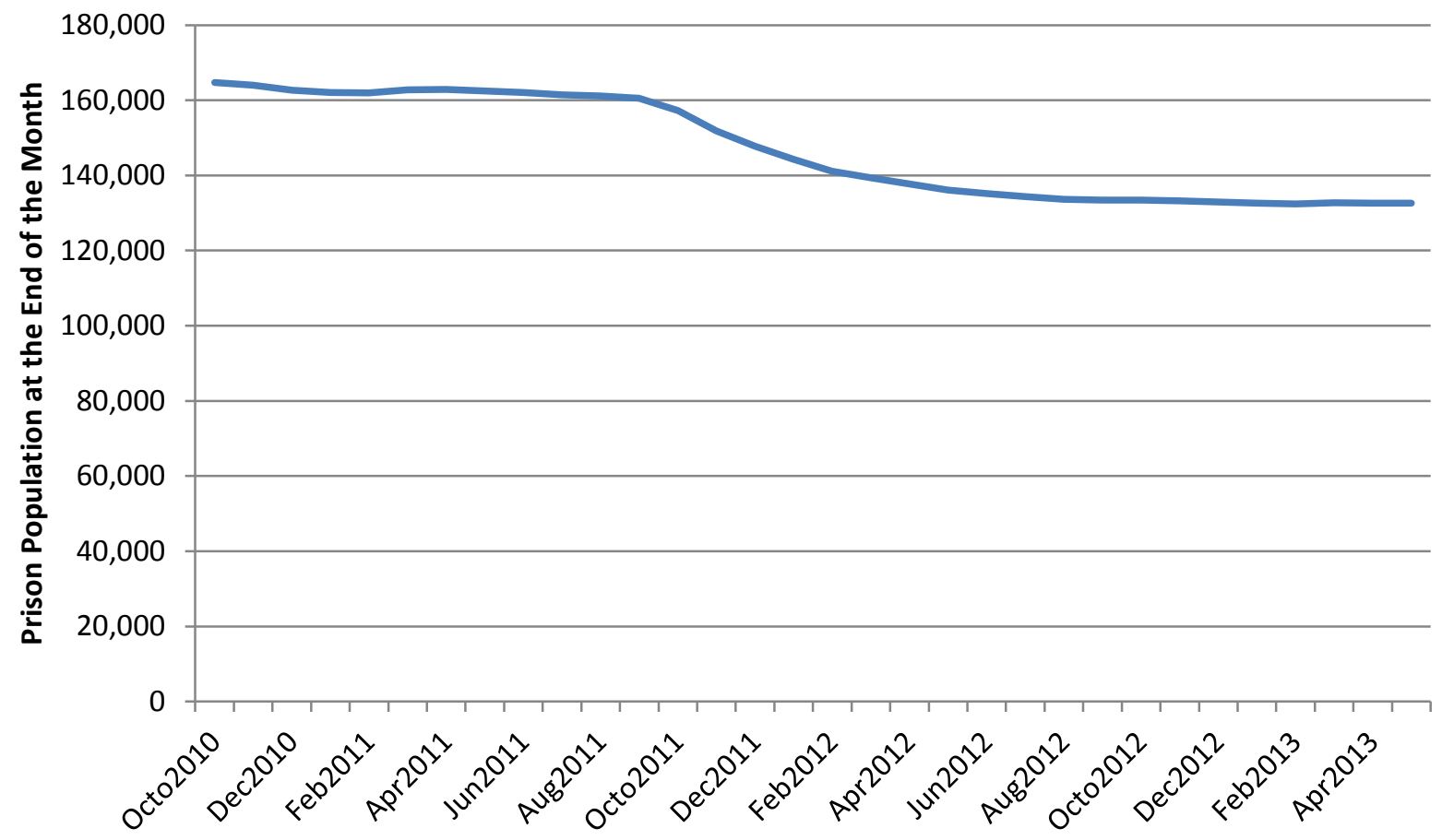

Figure 4: Scatter Plot of the Pre-Post Realignment Change in County-Level Prison Incarceration Rates Against the County-Level Prison Incarceration Rate in June 2011

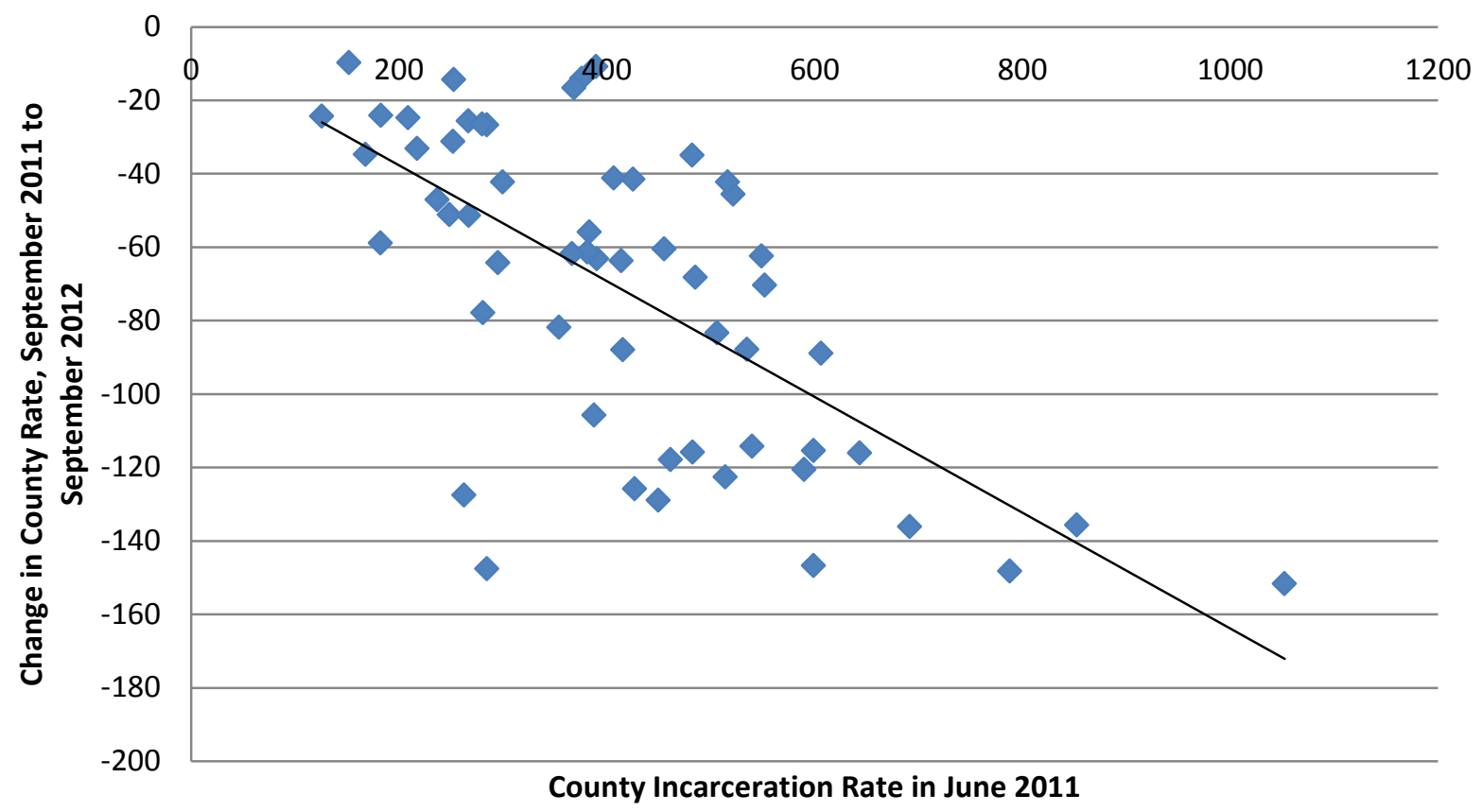


Figure 5: Aggregate Average Daily Jail Population, October 2010 through December 2012

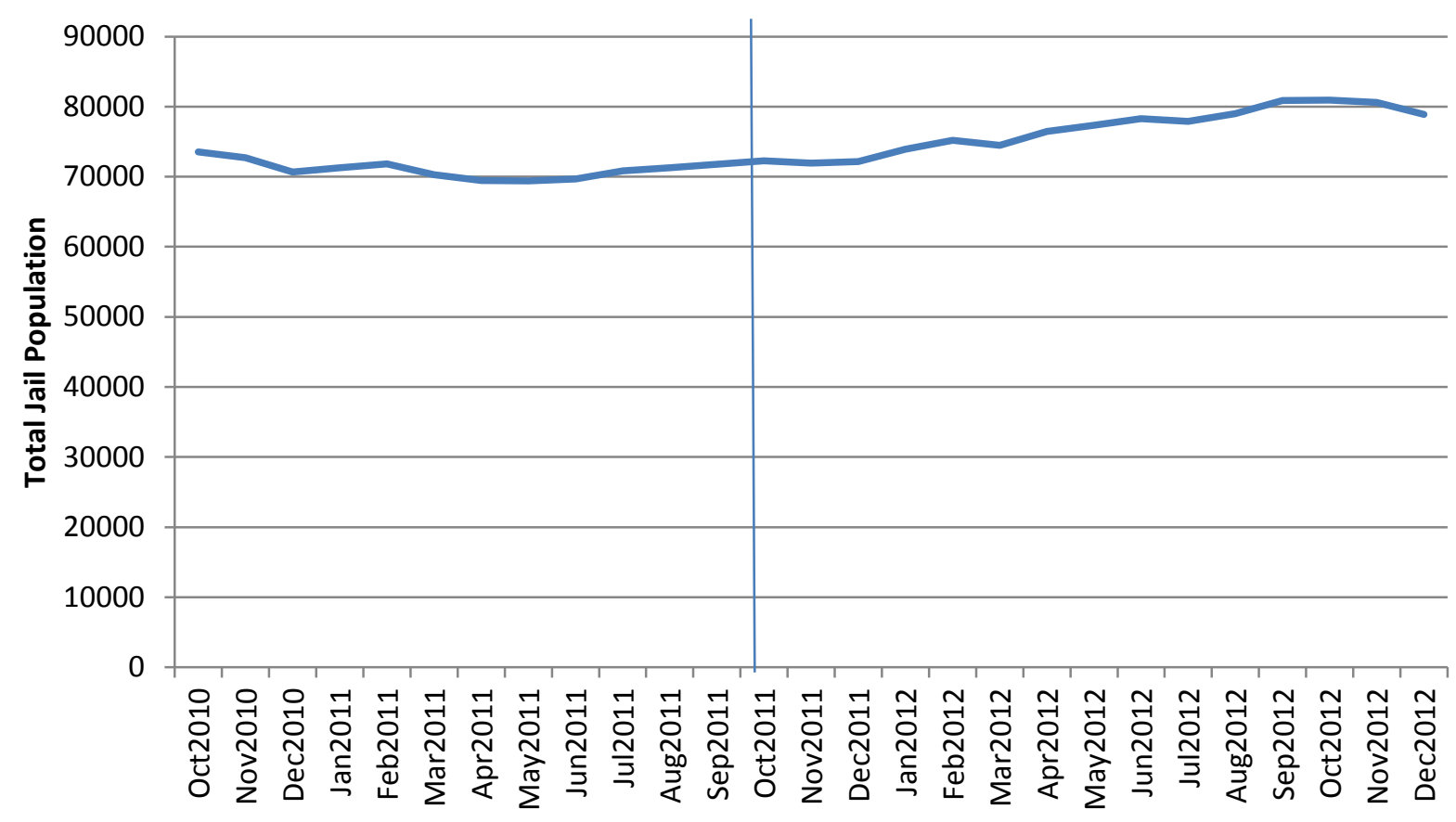

Figure 6: Total Monthly Violent Crimes in California, January 2010 through December 2012

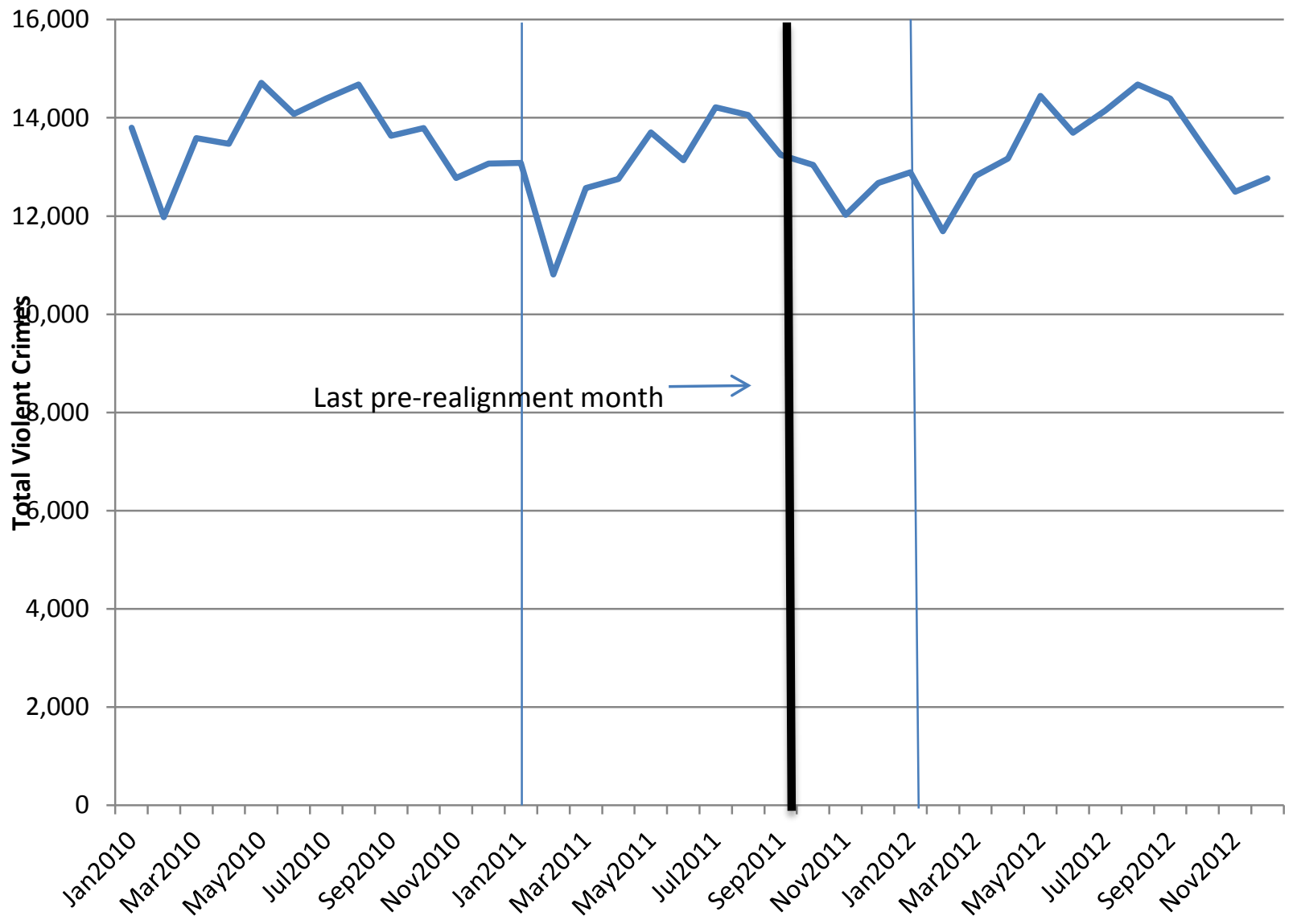


Figure 7: Total Monthly Property Crimes in California, January 2010 through December 2012

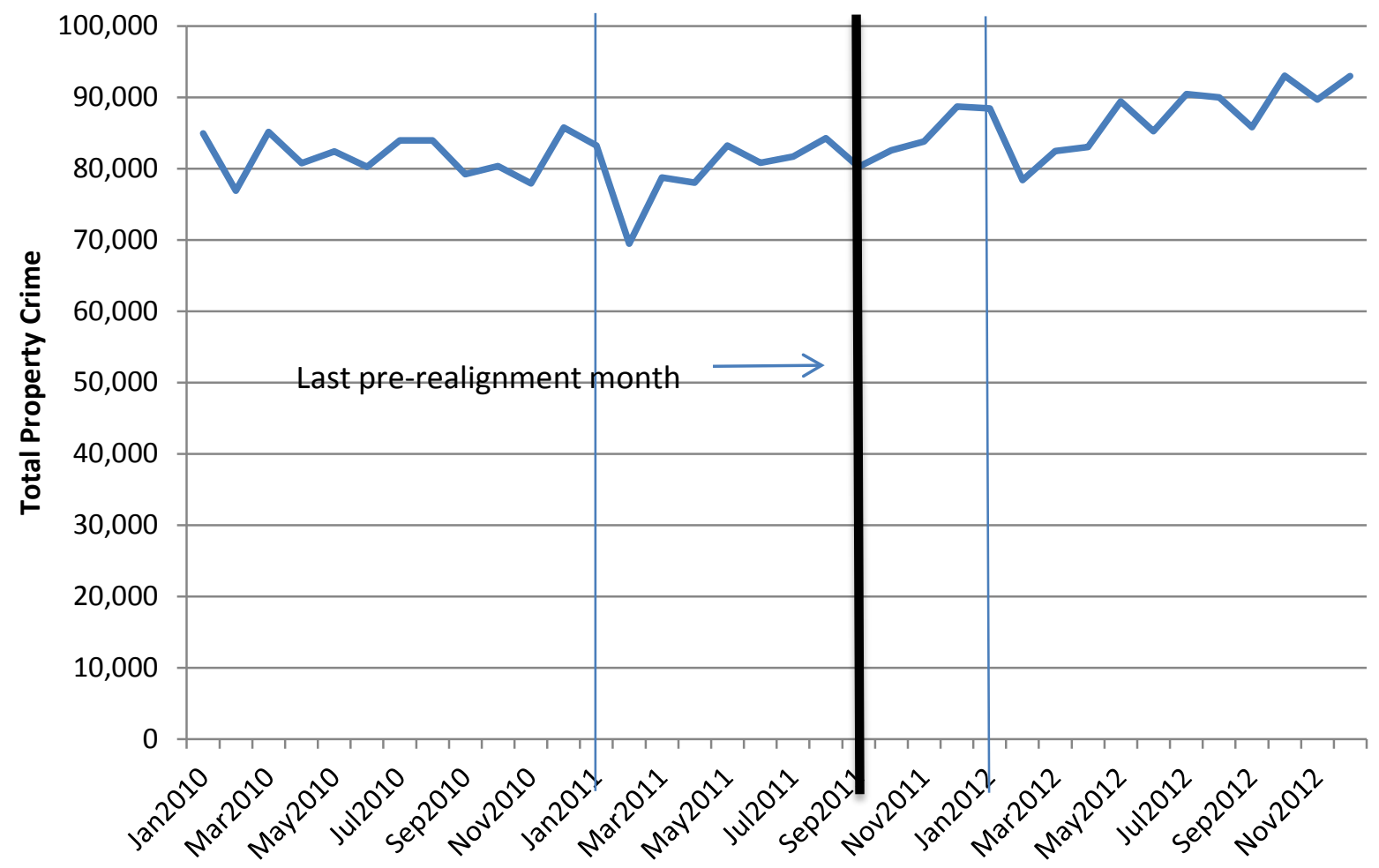

Figure 8: Scatter Plots of Two Alternative Measures of the Change in Violent and Property Crime at the County Level Against Corrsponding Changes in County-Specific Prison Incarceration Rates
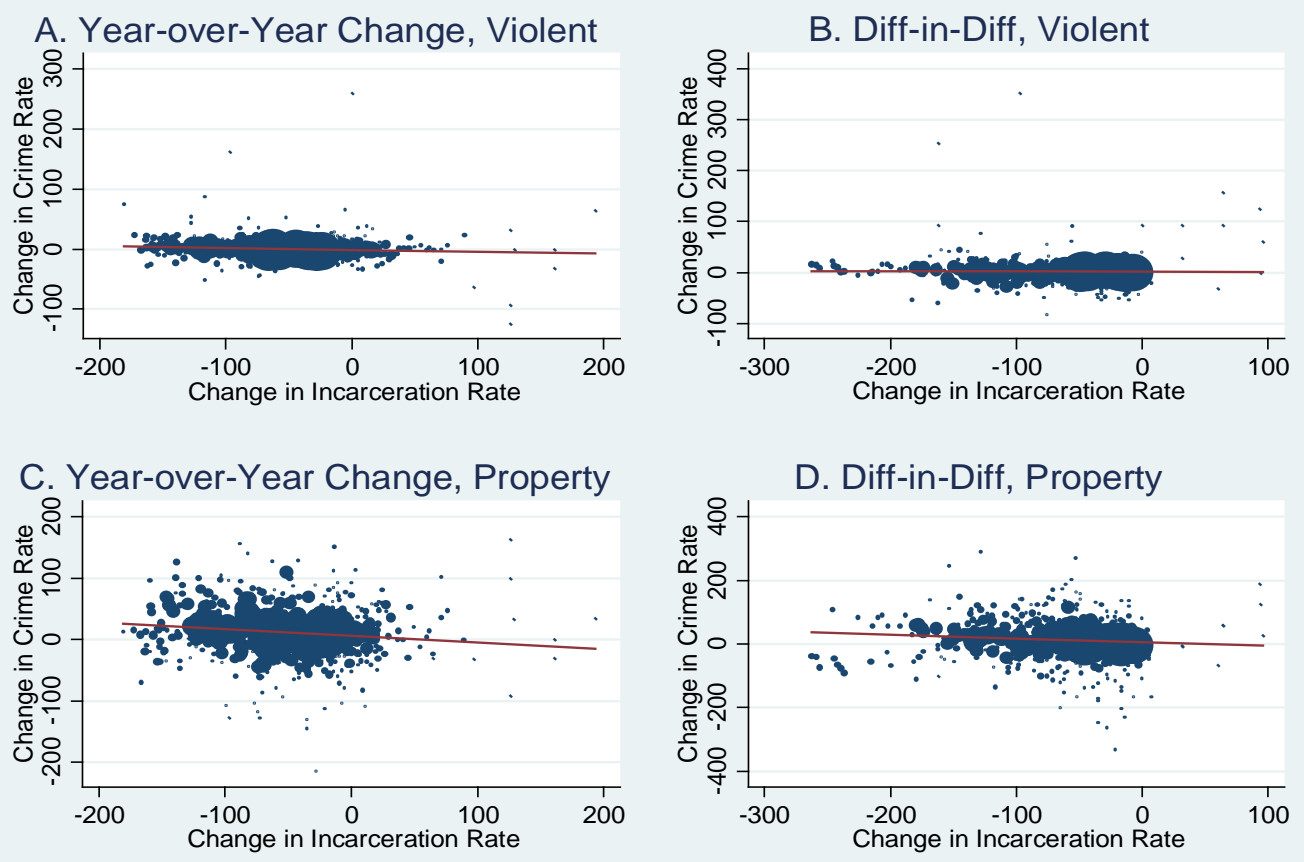
Figure 9: Violent Crime Rate Trends in California and Synthetic California, with Synthetic Comparison Group and Weighted Identified by Matching on Violent Crime Rates for Each Year Between 2000 and 2010

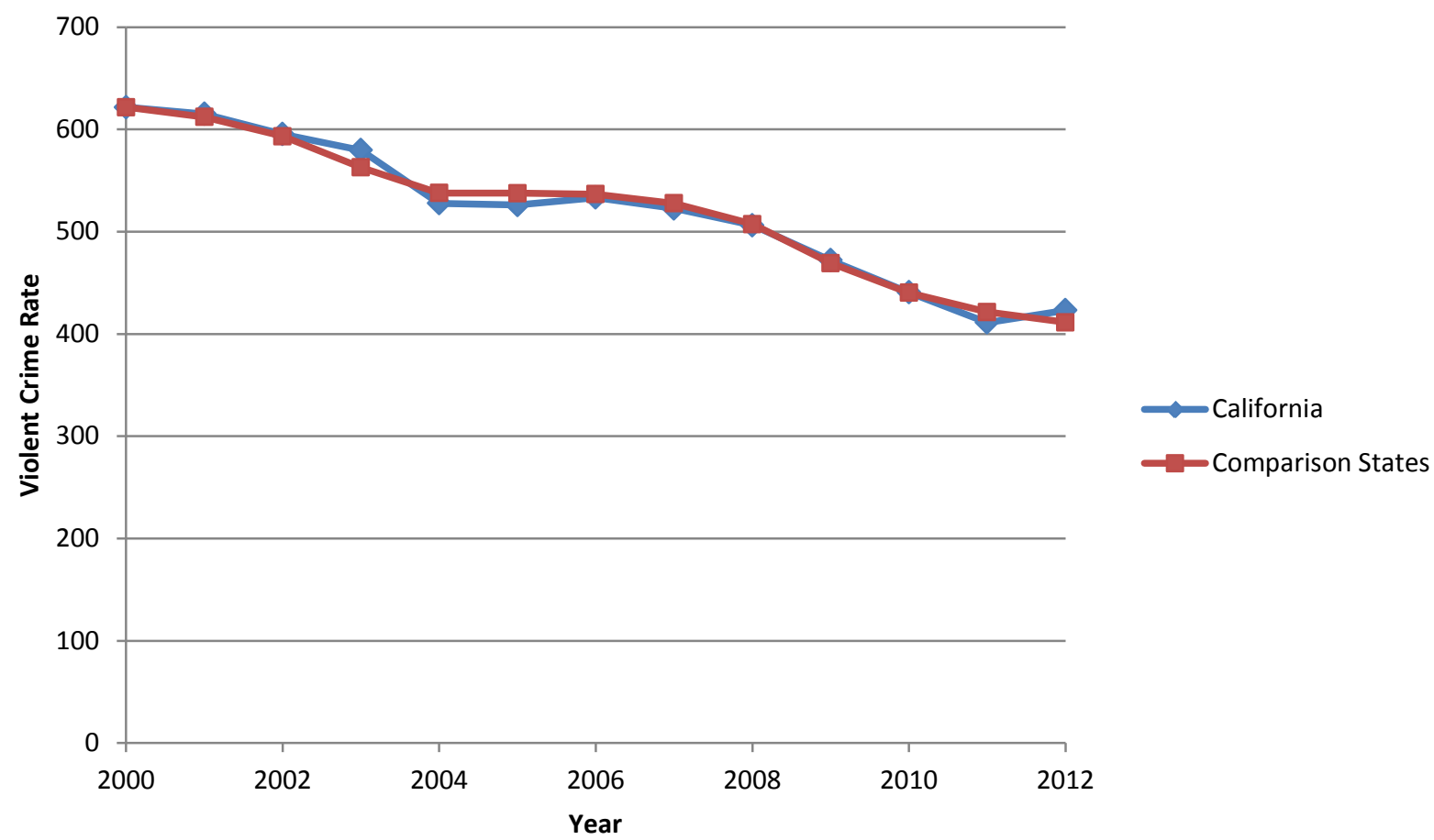

Figure 10: Property Crime Rate Trends in California and Synthetic California, with Synthetic Comparison Group and Weighted Identified by Matching on Violent Crime Rates for Each Year Between 2000 and 2010

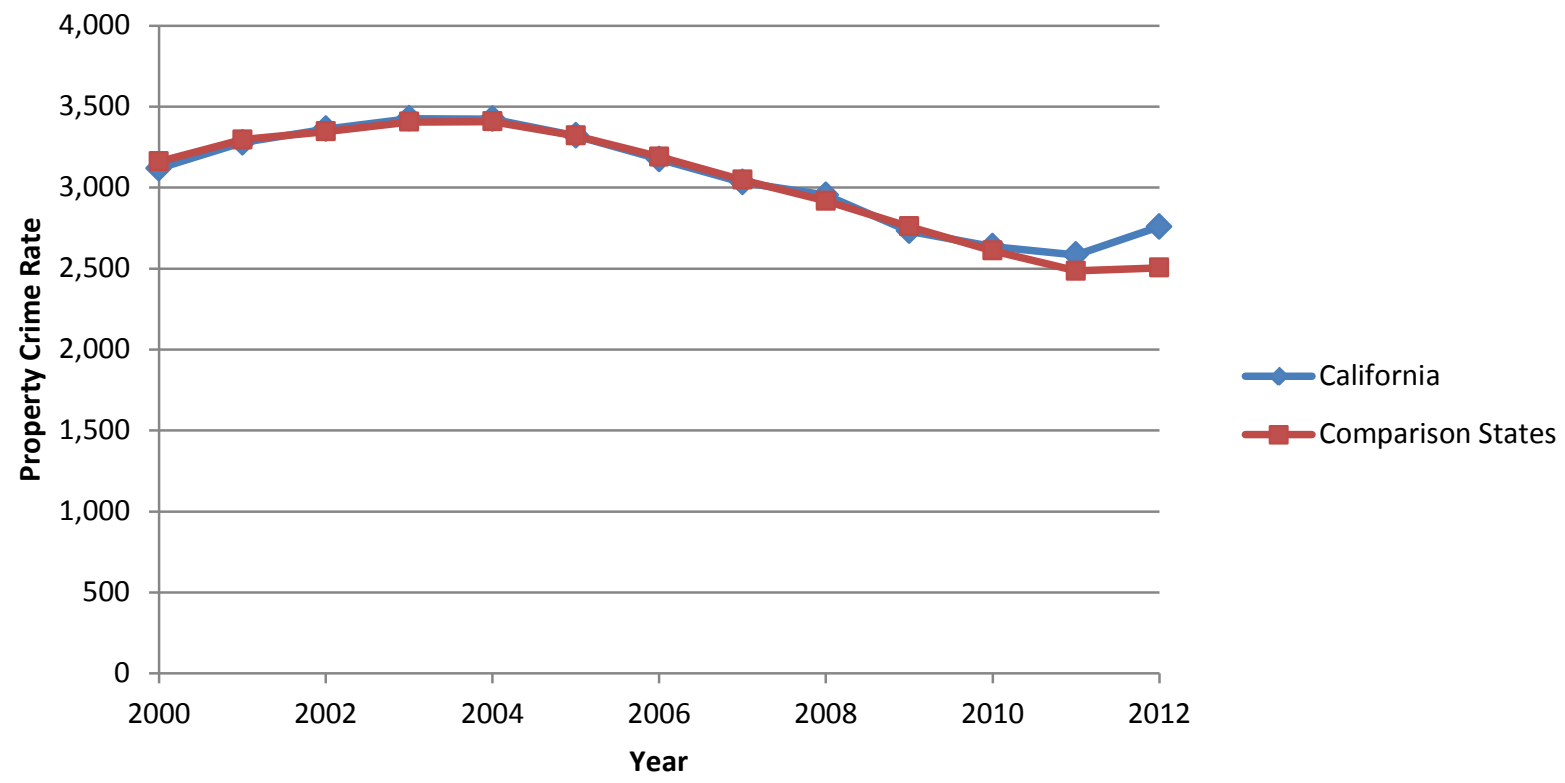




\section{Table 1}

Characteristics of Counties Stratified by their Pre-Realignment (June 2011) County-Specific Prison Incarceration Rate

\begin{tabular}{|c|c|c|c|}
\hline & Bottom third & Middle third & Top third \\
\hline $\begin{array}{l}\text { Incarceration rate, } \\
\text { June } 2011\end{array}$ & 234.1 & 401.7 & 611.7 \\
\hline $\begin{array}{l}\text { Poverty rate, } 2006 \text { to } \\
2010\end{array}$ & 10.9 & 14.3 & 17.6 \\
\hline $\begin{array}{lll}\text { Percent voting } & \text { for } \\
\text { Prop. } 36 & & \end{array}$ & 70.2 & 65.2 & 62.4 \\
\hline $\begin{array}{l}\text { Property crime rate } \\
2011\end{array}$ & $1,292.8$ & $1,354.8$ & $1,768.1$ \\
\hline $\begin{array}{l}\text { Violent crime rate } \\
2011\end{array}$ & 331.4 & 356.8 & 467.4 \\
\hline \multicolumn{4}{|c|}{$\begin{array}{l}\text { Tabulations do not include Alpine county in Northern California from this and subsequent } \\
\text { analysis due to the fact that Alpine does not maintain its own local jail system. Data on county } \\
\text { poverty rates comes from the Census Bureau American Community Survey. The percent of } \\
\text { county voters supporting proposition } 36 \text { comes from the California Secretary of State. Data on } \\
\text { property and violent crime for } 2011 \text { come from agency level crime counts provided by the } \\
\text { California State Attorney General's office. }\end{array}$} \\
\hline
\end{tabular}




\begin{tabular}{|c|c|c|c|c|}
\hline \multicolumn{5}{|c|}{$\begin{array}{l}\text { Table } 2 \\
\text { Cross-County Regression } \\
\text { Prison Incarceration Rate }\end{array}$} \\
\hline $\begin{array}{l}\text { Explanatory } \\
\text { variable }\end{array}$ & $\begin{array}{l}\text { Regression } \\
\text { coefficients }\end{array}$ & $\begin{array}{l}25^{\text {th }} \text { percentile of } \\
\text { explanatory } \\
\text { variable }\end{array}$ & $\begin{array}{l}75^{\text {th }} \text { percentile of } \\
\text { the explanatory } \\
\text { variable }\end{array}$ & $\begin{array}{l}\text { Effect on } \\
\text { incarceration } \\
\text { rate of a } \\
\text { variation equal } \\
\text { to the inter- } \\
\text { quartile range }\end{array}$ \\
\hline $\begin{array}{l}\text { Poverty rate, } \\
2006 \text { to } 2010\end{array}$ & $\begin{array}{l}18.24^{\mathrm{a}} \\
(5.34)\end{array}$ & 10.9 & 17.5 & 120.4 \\
\hline $\begin{array}{l}\text { Percent voting } \\
\text { for Prop. } 36\end{array}$ & $\begin{array}{l}-7.11^{\mathrm{a}} \\
(2.58)\end{array}$ & 60.7 & 70.9 & -72.5 \\
\hline $\begin{array}{l}\text { Property crime } \\
\text { rate } 2011\end{array}$ & $\begin{array}{l}-0.023 \\
(0.050)\end{array}$ & $1,134.2$ & $1,782.3$ & -14.9 \\
\hline $\begin{array}{ll}\text { Violent } & \text { crime } \\
\text { rate } 2011 & \end{array}$ & $\begin{array}{l}0.168 \\
(0.155)\end{array}$ & 258.2 & 479.1 & 37.1 \\
\hline $\mathrm{R}^{2}$ & 0.463 & - & - & - \\
\hline $\mathrm{N}$ & 57 & - & - & - \\
\hline
\end{tabular}

Standard errors are in parentheses. The regression is based on 57 of California's 58 counties. We drop Alpine county in Northern California from this and subsequent analysis due to the fact that Alpine does not maintain its own local jail system. Data on county poverty rates comes from the Census Bureau American Community Survey. The percent of county voters supporting proposition 36 comes from the California Secretary of State. Data on property and violent crime for 2011 come from agency level crime counts provided by the California State Attorney General's office.
a. Statistically significant at the one percent level of confidence.
b. Statistically significant at the five percent level of confidence.
c. Statistically significant at the ten percent level of confidence. 


\begin{tabular}{|c|c|c|c|c|c|c|}
\hline \multicolumn{7}{|l|}{$\begin{array}{l}\text { Table } 3 \\
\text { Annual Crimes P }\end{array}$} \\
\hline Crime Category & 2011 & 2012 & 2012 & $\begin{array}{l}\Delta, \quad 2010-2011 \\
(\text { percent } \Delta)\end{array}$ & $\begin{array}{l}\Delta, \quad 2011-2012 \\
(\text { percent } \Delta)\end{array}$ & $\begin{array}{l}\Delta, \quad 2010-2012 \\
(\text { percent } \Delta)\end{array}$ \\
\hline Total Violent & 439.2 & 412.1 & 422.2 & $-27.0(-6.2)$ & $10.1(2.5)$ & $-16.9(-3.9)$ \\
\hline Homicide & 4.8 & 4.8 & 4.9 & $-0.1(1.7)$ & $0.2(3.7)$ & $0.1(1.9)$ \\
\hline Rape & 22.3 & 20.4 & 20.6 & $-1.9(-8.6)$ & $0.2(1.0)$ & $-1.7(-7.7)$ \\
\hline Robbery & 155.6 & 144.2 & 148.5 & $-11.4(-7.3)$ & $4.3(2.9)$ & $-7.1(-4.6)$ \\
\hline $\begin{array}{l}\text { Aggravated } \\
\text { Assault }\end{array}$ & 256.4 & 242.8 & 248.2 & $-13.6(-5.3)$ & $5.5(2.3)$ & $-8.2(-3.2)$ \\
\hline Total Property & $2,692.0$ & $2,586.4$ & $2,756.9$ & $-42.6(-1.6)$ & $170.5(6.6)$ & $127.9(4.9)$ \\
\hline Burglary & 612.5 & 611.2 & 645.6 & $-1.3(-0.2)$ & $34.4(5.6)$ & $33.1(5.4)$ \\
\hline Larceny & $1,608.1$ & $1,585.0$ & $1,668.3$ & $-23.0(1.4)$ & $83.3(5.3)$ & $60.3(3.7)$ \\
\hline Vehicle Theft & 408.5 & 390.2 & 443.0 & $-18.3(-4.5)$ & $52.8(13.5)$ & $34.5(8.5)$ \\
\hline
\end{tabular}

Crime data come from the California Criminal Justice Statistics Center. Population data are from the census bureau and measure the state population as of July in each calendar year. 


\begin{tabular}{|c|c|c|c|c|c|}
\hline \multicolumn{6}{|c|}{$\begin{array}{l}\text { Table } 4 \\
\text { Regression Estimates of the Prison-Crime Effects for Overall Violent Crime and Overall Property Crime }\end{array}$} \\
\hline \multicolumn{6}{|c|}{ Panel A: Total Violent Crime } \\
\hline $\begin{array}{l}\text { Year-over-Year } \\
\text { Changes }\end{array}$ & No fixed effects & No fixed effects & Month effects & County effects & $\begin{array}{l}\text { Month and county } \\
\text { effects }\end{array}$ \\
\hline$\Delta$ Prison & $-0.033^{\mathrm{a}}(0.008)$ & $-0.034^{\mathrm{a}}(0.007)$ & $-0.019^{b}(0.009)$ & $-0.040^{\mathrm{a}}(0.013)$ & $0.009(0.016)$ \\
\hline$\Delta$ Jail & - & $-0.011(0.016)$ & $-0.027(0.0019)$ & $0.013(0.022)$ & $-0.029(0.022)$ \\
\hline $\begin{array}{l}\text { Difference-in- } \\
\text { Difference Changes }\end{array}$ & No fixed effects & No fixed effects & Month effects & County effects & $\begin{array}{l}\text { Month and county } \\
\text { effects }\end{array}$ \\
\hline$\Delta$ Prison & $-0.006(0.022)$ & $-0.017(0.019)$ & $0.005(0.025)$ & $-0.041^{\mathrm{a}}(0.014)$ & $0.009(0.017)$ \\
\hline$\Delta$ Jail & - & $-0.047^{c}(0.026)$ & $-0.069^{\mathrm{b}}(0.027)$ & $0.013(0.022)$ & $-0.029(0.022)$ \\
\hline \multicolumn{6}{|c|}{ Panel B: Total Property Crime } \\
\hline $\begin{array}{l}\text { Year-over-Year } \\
\text { Changes }\end{array}$ & No fixed effects & No fixed effects & Month effects & County effects & $\begin{array}{l}\text { Month and county } \\
\text { effects }\end{array}$ \\
\hline$\Delta$ Prison & $-0.107^{c}(0.053)$ & $-0.164^{\mathrm{a}}(0.056)$ & $-0.122^{c}(0.070)$ & $-0.162^{\mathrm{a}}(0.053)$ & $-0.089(0.087)$ \\
\hline$\Delta$ Jail & - & $-0.317^{a}(0.079)$ & $-0.348^{\mathrm{a}}(0.081)$ & $-0.149^{c}(0.086)$ & $-0.162^{c}(0.097)$ \\
\hline $\begin{array}{l}\text { Difference-in- } \\
\text { Difference Changes }\end{array}$ & No fixed effects & No fixed effects & Month effects & County effects & $\begin{array}{l}\text { Month and county } \\
\text { effects }\end{array}$ \\
\hline$\Delta$ Prison & $-0.117^{b}(0.068)$ & $-0.183^{b}(0.073)$ & $-0.159^{c}(0.086)$ & $-0.165^{\mathrm{a}}(0.054)$ & $-0.091(0.089)$ \\
\hline$\Delta$ Jail & - & $-0.285^{\mathrm{a}}(0.095)$ & $-0.299^{\mathrm{a}}(0.101)$ & $-0.152^{c}(0.086)$ & $-0.163^{c}(0.097)$ \\
\hline
\end{tabular}

Standard errors are in parentheses. Standard errors are calculated assuming clustering by county. Each Regression contains 684 county-month observations. See main text for description of the alternative characterizations of the dependent and explanatory variables.

a. Statistically significant at the one percent level of confidence.

b. Statistically significant at the five percent level of confidence.

c. Statistically significant at the ten percent level of confidence. 


\begin{tabular}{|c|c|c|c|c|c|}
\hline \multicolumn{6}{|c|}{$\begin{array}{l}\text { Table } 5 \\
\text { Regression Estimates of the Prison-Crime Effects for Individual Violent Crimes }\end{array}$} \\
\hline & $\begin{array}{l}\text { No fixed effects, no } \\
\text { control for jail } \\
\text { change }\end{array}$ & $\begin{array}{l}\text { No fixed effects, } \\
\text { control for jail } \\
\text { change }\end{array}$ & Month effects & County effects & $\begin{array}{l}\text { Month and county } \\
\text { effects }\end{array}$ \\
\hline \multicolumn{6}{|l|}{ Murder } \\
\hline Year-over-Year & $-0.0004(0.0004)$ & $-0.0004(0.0004)$ & $-0.0005(0.0005)$ & $-0.001(0.001)$ & $-0.001(0.001)$ \\
\hline Diff-in-Diff & $-0.001(0.001)$ & $-0.0017(0.0012)$ & $-0.0016(0.0014)$ & $-0.001(0.001)$ & $-0.001(0.002)$ \\
\hline \multicolumn{6}{|l|}{ Rape } \\
\hline Year-over-Year & $-0.001(0.001)$ & $-0.001(0.001)$ & $0.000(0.001)$ & $-0.002(0.002)$ & $-0.002(0.004)$ \\
\hline Diff-in-Diff & $0.003(0.002)$ & $0.004^{c}(0.003)$ & $0.006^{c}(0.003)$ & $-0.002(0.002)$ & $-0.001(0.003)$ \\
\hline \multicolumn{6}{|l|}{ Robbery } \\
\hline Year-over-Year & $-0.009^{c}(0.005)$ & $-0.012^{b}(0.005)$ & $-0.005(0.005)$ & $-0.015^{c}(0.008)$ & $0.004(0.010)$ \\
\hline Diff-in-Diff & $0.001(0.010)$ & $-0.003(0.010)$ & $0.006(0.013)$ & $-0.016^{c}(0.008)$ & $0.004(0.010)$ \\
\hline \multicolumn{6}{|c|}{ Aggravated Assault } \\
\hline Year-over-Year & $-0.022^{\mathrm{a}}(0.007)$ & $-0.021^{a}(0.006)$ & $-0.014^{c}(0.008)$ & $-0.022^{C}(0.012)$ & $0.008(0.014)$ \\
\hline Diff-in-Diff & $-0.008(0.015)$ & $-0.017(0.012)$ & $-0.004(0.015)$ & $-0.023^{c}(0.012)$ & $0.007(0.015)$ \\
\hline
\end{tabular}

Standard errors are in parentheses. Standard errors are calculated assuming clustering by county. Each Regression contains 684 county-month observations. See main text for description of the alternative characterizations of the dependent and explanatory variables.
a. Statistically significant at the one percent level of confidence.
b. Statistically significant at the five percent level of confidence.
c. Statistically significant at the ten percent level of confidence. 


\begin{tabular}{|c|c|c|c|c|c|}
\hline \multicolumn{6}{|c|}{$\begin{array}{l}\text { Table } 6 \\
\text { Regression Estimates of the Prison-Crime Effects for Individual Property Crimes }\end{array}$} \\
\hline & No fixed effects & No fixed effects & Month effects & County effects & $\begin{array}{l}\text { Month and county } \\
\text { effects }\end{array}$ \\
\hline \multicolumn{6}{|l|}{ Burglary } \\
\hline Year-over-Year & $-0.005(0.019)$ & $-0.012(0.022)$ & $-0.013(0.030)$ & $-0.004(0.027)$ & $0.019(0.041)$ \\
\hline Diff-in-Diff & $-0.032(0.031)$ & $-0.079^{a}(0.024)$ & $-0.076^{a}(0.028)$ & $-0.003(0.027)$ & $0.024(0.042)$ \\
\hline \multicolumn{6}{|l|}{ Larceny } \\
\hline Year-over-Year & $-0.045(0.033)$ & $-0.073^{c}(0.039)$ & $-0.047(0.040)$ & $-0.078^{c}(0.042)$ & $-0.010(0.073)$ \\
\hline Diff-in-Diff & $-0.016(0.038)$ & $-0.035(0.039)$ & $-0.014(0.044)$ & $-0.081^{\mathrm{c}}(0.043)$ & $-0.013(0.075)$ \\
\hline \multicolumn{6}{|c|}{ Motor Vehicle Theft } \\
\hline Year-over-Year & $-0.057^{\mathrm{a}}(0.018)$ & $-0.080^{\mathrm{a}}(0.017)$ & $-0.062^{\mathrm{a}}(0.020)$ & $-0.080^{\mathrm{a}}(0.023)$ & $-0.099^{a}(0.036)$ \\
\hline Diff-in-Diff & $-0.068^{\mathrm{a}}(0.024)$ & $-0.069^{b}(0.029)$ & $-0.069^{c}(0.037)$ & $-0.081^{\mathrm{a}}(0.023)$ & $-0.103^{\mathrm{a}}(0.037)$ \\
\hline
\end{tabular}

Standard errors are in parentheses. Standard errors are calculated assuming clustering by county. Each Regression contains 684 county-month observations. See main text for description of the alternative characterizations of the dependent and explanatory variables.

a. Statistically significant at the one percent level of confidence.

b. Statistically significant at the five percent level of confidence.

c. Statistically significant at the ten percent level of confidence. 


\begin{tabular}{|c|c|c|c|c|c|c|}
\hline \multicolumn{7}{|l|}{$\begin{array}{l}\text { Table } 7 \\
\text { Estimated }\end{array}$} \\
\hline \multirow{3}{*}{ Year } & \multicolumn{3}{|c|}{ Violent Crime Rate } & \multicolumn{3}{|c|}{ Property Crime Rate } \\
\hline & California & Synthetic & Difference & California & Synthetic & Difference \\
\hline & & California & & & California & \\
\hline 2000 & 621.6 & 621.7 & -0.06 & 3118.2 & 3161.0 & -42.77 \\
\hline 2001 & 615.2 & 612.2 & 3.01 & 3278.0 & 3295.7 & -17.72 \\
\hline 2002 & 595.4 & 593.3 & 2.07 & 3361.2 & 3346.1 & 15.07 \\
\hline 2003 & 579.6 & 562.8 & 16.77 & 3426.4 & 3405.2 & 21.23 \\
\hline 2004 & 527.8 & 537.8 & -9.99 & 3423.9 & 3408.6 & 15.31 \\
\hline 2005 & 526.0 & 537.6 & -11.55 & 3321.0 & 3320.6 & 0.40 \\
\hline 2006 & 533.3 & 536.6 & -3.31 & 3175.2 & 3190.0 & -14.80 \\
\hline 2007 & 522.6 & 527.7 & -5.13 & 3032.6 & 3048.4 & -15.76 \\
\hline 2008 & 506.2 & 507.3 & -1.08 & 2954.5 & 2917.5 & 37.01 \\
\hline 2009 & 472.0 & 469.3 & 2.73 & 2731.5 & 2759.5 & -27.95 \\
\hline 2010 & 440.6 & 440.3 & 0.33 & 2635.8 & 2610.2 & 25.64 \\
\hline 2011 & 411.2 & 421.5 & -10.28 & 2584.2 & 2485.5 & 98.70 \\
\hline 2012 & 423.1 & 411.4 & 11.72 & 2758.7 & 2505.5 & 253.15 \\
\hline Pre-Period & $\begin{array}{l}2006- \\
2010\end{array}$ & $\begin{array}{l}2008- \\
2010\end{array}$ & 2010 & $\begin{array}{l}2006- \\
2010\end{array}$ & $\begin{array}{l}2008- \\
2010\end{array}$ & 2010 \\
\hline $\begin{array}{l}\text { Pre-reform } \\
\text { difference }\end{array}$ & -1.29 & 0.66 & 0.33 & 0.83 & 11.57 & 25.64 \\
\hline $\begin{array}{l}\text { Post-reform } \\
\text { difference }\end{array}$ & 11.72 & 11.72 & 11.72 & 253.15 & 253.15 & 253.15 \\
\hline $\begin{array}{l}\text { Difference- } \\
\text { in- } \\
\text { Difference }\end{array}$ & 13.01 & 11.06 & 11.39 & 252.32 & 241.58 & 227.51 \\
\hline $\begin{array}{l}\text { Placebo } \\
\text { Test, Rank }\end{array}$ & 14 & 13 & 13 & 5 & 5 & 5 \\
\hline $\begin{array}{l}\text { P-Value } \\
\text { (One tail) }\end{array}$ & 0.286 & 0.265 & 0.265 & 0.102 & 0.102 & 0.102 \\
\hline
\end{tabular}




\begin{tabular}{|c|c|c|c|c|c|c|c|c|c|c|c|c|}
\hline \multicolumn{13}{|c|}{ Table 8} \\
\hline \multicolumn{13}{|c|}{ Estimated Impact of Realignment on Violent Crimes using the Synthetic Control Method } \\
\hline \multirow[b]{2}{*}{ Year } & \multicolumn{3}{|c|}{ Murder } & \multicolumn{3}{|c|}{ Rape } & \multicolumn{3}{|c|}{ Robbery } & \multicolumn{3}{|c|}{ Aggravated Assault } \\
\hline & California & $\begin{array}{l}\text { Synthetic } \\
\text { California }\end{array}$ & Difference & California & $\begin{array}{l}\text { Synthetic } \\
\text { California }\end{array}$ & Difference & California & $\begin{array}{l}\text { Synthetic } \\
\text { California }\end{array}$ & Difference & California & $\begin{array}{l}\text { Synthetic } \\
\text { California }\end{array}$ & Difference \\
\hline 2000 & 6.1 & 6.0 & 0.06 & 28.9 & 28.9 & 0.03 & 177.9 & 179.1 & -1.17 & 408.7 & 395.3 & 13.39 \\
\hline 2001 & 6.4 & 6.5 & -0.05 & 28.8 & 28.8 & 0.03 & 186.7 & 185.1 & 1.56 & 393.3 & 387.2 & 6.05 \\
\hline 2002 & 6.8 & 6.8 & 0.03 & 29.1 & 29.0 & 0.09 & 185.6 & 185.9 & -0.32 & 373.8 & 377.7 & -3.87 \\
\hline 2003 & 6.8 & 6.8 & -0.03 & 28.2 & 28.2 & 0.02 & 179.8 & 180.2 & -0.43 & 364.8 & 338.2 & 26.62 \\
\hline 2004 & 6.7 & 6.6 & 0.14 & 26.8 & 26.8 & 0.05 & 172.3 & 172.9 & -0.58 & 322.0 & 336.7 & -14.72 \\
\hline 2005 & 6.9 & 6.8 & 0.11 & 26.0 & 26.0 & -0.03 & 176.0 & 176.1 & -0.12 & 317.1 & 321.0 & -3.91 \\
\hline 2006 & 6.8 & 6.8 & 0.02 & 25.3 & 25.3 & 0.01 & 195.0 & 196.3 & -1.26 & 306.2 & 312.1 & -5.95 \\
\hline 2007 & 6.2 & 6.4 & -0.16 & 24.7 & 24.6 & 0.06 & 193.0 & 192.9 & 0.10 & 298.8 & 301.2 & -2.41 \\
\hline 2008 & 5.9 & 5.9 & 0.00 & 24.3 & 24.3 & 0.00 & 189.7 & 189.5 & 0.24 & 286.3 & 291.5 & -5.17 \\
\hline 2009 & 5.3 & 5.4 & -0.08 & 23.6 & 23.6 & 0.04 & 173.4 & 173.6 & -0.25 & 269.7 & 278.2 & -8.48 \\
\hline 2010 & 4.9 & 4.9 & -0.04 & 22.4 & 22.4 & 0.00 & 156.0 & 154.9 & 1.10 & 257.4 & 262.7 & -5.32 \\
\hline 2011 & 4.8 & 4.9 & -0.09 & 20.3 & 22.3 & -2.01 & 144.1 & 143.4 & 0.73 & 242.0 & 243.9 & -1.93 \\
\hline 2012 & 5.0 & 4.6 & 0.42 & 20.6 & 21.5 & -0.88 & 148.6 & 141.6 & 6.97 & 248.9 & 237.8 & 11.11 \\
\hline Pre-Period & $\begin{array}{l}2006- \\
2010\end{array}$ & $\begin{array}{l}2008- \\
2010\end{array}$ & 2010 & $\begin{array}{l}2006- \\
2010\end{array}$ & $\begin{array}{l}2008- \\
2010\end{array}$ & 2010 & $\begin{array}{l}2006- \\
2010\end{array}$ & $\begin{array}{l}2008- \\
2010\end{array}$ & 2010 & $\begin{array}{l}2006- \\
2010\end{array}$ & $\begin{array}{l}2008- \\
2010\end{array}$ & 2010 \\
\hline $\begin{array}{l}\text { Pre-reform } \\
\text { diff }\end{array}$ & -0.05 & -0.04 & -0.04 & 0.02 & 0.01 & 0.00 & -0.01 & 0.36 & 1.10 & -5.46 & -6.32 & -5.32 \\
\hline $\begin{array}{l}\text { Post- } \\
\text { reform diff }\end{array}$ & 0.42 & 0.42 & 0.42 & -0.88 & -0.88 & -0.88 & 6.97 & 6.97 & 6.97 & 11.11 & 11.11 & 11.11 \\
\hline Diff-in-Diff & 0.47 & 0.46 & 0.46 & -0.89 & -0.89 & -0.87 & 6.99 & 6.61 & 5.87 & 16.57 & 17.43 & 16.43 \\
\hline $\begin{array}{l}\text { Placebo } \\
\text { Test, Rank }\end{array}$ & 11 & 10 & 11 & 30 & 28 & 27 & 4 & 4 & 10 & 9 & 9 & 9 \\
\hline $\begin{array}{l}\text { P-Val(One } \\
\text { tail) }\end{array}$ & 0.224 & 0.204 & 0.224 & 0.612 & 0.571 & 0.551 & 0.082 & 0.082 & 0.204 & 0.184 & 0.184 & 0.184 \\
\hline
\end{tabular}




\begin{tabular}{|c|c|c|c|c|c|c|c|c|c|}
\hline \multicolumn{10}{|c|}{$\begin{array}{l}\text { Table } 9 \\
\text { Estimated Impact of } R\end{array}$} \\
\hline \multirow[b]{2}{*}{ Year } & \multicolumn{3}{|c|}{ Burglary } & \multicolumn{3}{|c|}{ Motor Vehicle Theft } & \multicolumn{3}{|c|}{ Larceny Theft } \\
\hline & California & $\begin{array}{l}\text { Synthetic } \\
\text { California }\end{array}$ & Difference & California & $\begin{array}{l}\text { Synthetic } \\
\text { California }\end{array}$ & Difference & California & $\begin{array}{l}\text { Synthetic } \\
\text { California }\end{array}$ & Difference \\
\hline 2000 & 656.3 & 655.0 & 1.26 & 537.4 & 552.3 & -14.86 & 1924.5 & 2001.7 & -77.20 \\
\hline 2001 & 671.3 & 670.0 & 1.27 & 590.1 & 573.8 & 16.26 & 2016.6 & 2010.0 & 6.59 \\
\hline 2002 & 681.2 & 680.0 & 1.21 & 635.3 & 630.7 & 4.62 & 2044.7 & 2020.7 & 24.03 \\
\hline 2003 & 683.2 & 682.0 & 1.23 & 680.5 & 695.0 & -14.54 & 2062.7 & 2049.8 & 12.95 \\
\hline 2004 & 686.1 & 684.9 & 1.25 & 704.8 & 695.2 & 9.57 & 2033.1 & 1990.2 & 42.89 \\
\hline 2005 & 692.9 & 691.6 & 1.30 & 712.0 & 729.4 & -17.38 & 1915.0 & 1934.6 & -19.57 \\
\hline 2006 & 676.9 & 675.6 & 1.30 & 666.8 & 689.3 & -22.55 & 1831.5 & 1837.1 & -5.62 \\
\hline 2007 & 648.4 & 647.2 & 1.23 & 600.2 & 596.7 & 3.51 & 1784.1 & 1788.3 & -4.22 \\
\hline 2008 & 649.9 & 648.7 & 1.23 & 526.3 & 480.1 & 46.17 & 1778.3 & 1781.0 & -2.67 \\
\hline 2009 & 622.6 & 621.4 & 1.25 & 443.8 & 381.9 & 61.95 & 1665.1 & 1692.5 & -27.38 \\
\hline 2010 & 614.3 & 613.1 & 1.19 & 409.4 & 336.8 & 72.56 & 1612.1 & 1612.0 & 0.13 \\
\hline 2011 & 610.5 & 623.5 & -12.97 & 389.7 & 312.4 & 77.35 & 1584.0 & 1551.2 & 32.81 \\
\hline 2012 & 646.1 & 603.7 & 42.42 & 443.2 & 300.6 & 142.55 & 1669.5 & 1646.4 & 23.06 \\
\hline Pre-Period & $\begin{array}{l}2006- \\
2010\end{array}$ & $\begin{array}{l}2008- \\
2010\end{array}$ & 2010 & $\begin{array}{l}2006- \\
2010\end{array}$ & $\begin{array}{l}2008- \\
2010\end{array}$ & 2010 & $\begin{array}{l}2006- \\
2010\end{array}$ & $\begin{array}{l}2008- \\
2010\end{array}$ & 2010 \\
\hline $\begin{array}{l}\text { Pre-reform } \\
\text { diff }\end{array}$ & 1.24 & 1.22 & 1.19 & 32.33 & 60.22 & 72.56 & -7.95 & -9.97 & 0.13 \\
\hline $\begin{array}{l}\text { Post- } \\
\text { reform diff }\end{array}$ & 42.42 & 42.42 & 42.42 & 142.55 & 142.55 & 142.55 & 23.06 & 23.06 & 23.06 \\
\hline Diff-in-diff & 41.18 & 41.19 & 41.23 & 110.22 & 82.33 & 69.99 & 31.01 & 33.03 & 22.92 \\
\hline $\begin{array}{l}\text { Placebo } \\
\text { Test, Rank }\end{array}$ & 13 & 13 & 12 & 1 & 1 & 1 & 15 & 15 & 20 \\
\hline $\begin{array}{l}\text { P-Value } \\
\text { (One tail) }\end{array}$ & 0.265 & 0.265 & 0.245 & 0.020 & 0.020 & 0.020 & 0.306 & 0.306 & 0.408 \\
\hline
\end{tabular}




\begin{tabular}{|c|c|c|c|c|c|c|c|c|c|}
\hline \multicolumn{10}{|c|}{$\begin{array}{l}\text { Appendix Table A1 } \\
\text { Estimated State Weight }\end{array}$} \\
\hline State & Violent & Murder & Rape & Robbery & $\begin{array}{l}\text { Aggravated } \\
\text { Assault }\end{array}$ & Property & Burglary & $\begin{array}{l}\text { Motor } \\
\text { Vehicle } \\
\text { Theft }\end{array}$ & $\begin{array}{l}\text { Larceny } \\
\text { Theft }\end{array}$ \\
\hline Alabama & 0 & 0 & 0 & 0 & 0 & 0 & 0.003 & 0 & 0 \\
\hline Alaska & 0 & 0 & 0 & 0 & 0 & 0 & 0.002 & 0 & 0 \\
\hline Arizona & 0 & 0 & 0 & 0.016 & 0 & 0 & 0.002 & 0.011 & 0 \\
\hline Arkansas & 0 & 0 & 0 & 0 & 0 & 0 & 0.015 & 0 & 0 \\
\hline Colorado & 0 & 0.278 & 0 & 0 & 0 & 0.033 & 0.213 & 0 & 0.12 \\
\hline Connecticut & 0 & 0 & 0 & 0 & 0 & 0 & 0.003 & 0 & 0 \\
\hline Delaware & 0 & 0 & 0 & 0.041 & 0 & 0 & 0.002 & 0 & 0 \\
\hline Florida & 0.338 & 0 & 0.117 & 0.135 & 0 & 0 & 0.004 & 0 & 0 \\
\hline Georgia & 0 & 0 & 0 & 0.048 & 0 & 0.001 & 0.032 & 0.368 & 0 \\
\hline Hawaii & 0 & 0 & 0.14 & 0 & 0 & 0 & 0.002 & 0.069 & 0 \\
\hline Idaho & 0 & 0 & 0 & 0 & 0 & 0 & 0.024 & 0 & 0 \\
\hline Illinois & 0 & 0 & 0 & 0.114 & 0.086 & 0 & 0.003 & 0 & 0 \\
\hline Indiana & 0 & 0 & 0 & 0 & 0 & 0 & 0.102 & 0 & 0 \\
\hline lowa & 0 & 0 & 0 & 0 & 0 & 0 & 0.004 & 0 & 0 \\
\hline Kansas & 0 & 0.033 & 0 & 0 & 0 & 0 & 0.001 & 0 & 0 \\
\hline Kentucky & 0 & 0 & 0 & 0 & 0 & 0.133 & 0.006 & 0 & 0 \\
\hline Louisiana & 0 & 0 & 0.003 & 0 & 0 & 0 & 0.001 & 0 & 0 \\
\hline Maine & 0 & 0 & 0 & 0 & 0 & 0 & 0.003 & 0 & 0 \\
\hline Maryland & 0.161 & 0.186 & 0.043 & 0.079 & 0.539 & 0 & 0.004 & 0.248 & 0 \\
\hline Massachusetts & 0 & 0 & 0 & 0 & 0 & 0.032 & 0.012 & 0 & 0.217 \\
\hline Michigan & 0 & 0 & 0 & 0 & 0 & 0 & 0.006 & 0 & 0 \\
\hline Minnesota & 0 & 0 & 0.03 & 0 & 0 & 0 & 0.01 & 0 & 0 \\
\hline Mississippi & 0 & 0.035 & 0 & 0 & 0.225 & 0 & 0.002 & 0 & 0 \\
\hline Missouri & 0 & 0 & 0 & 0 & 0 & 0 & 0.143 & 0 & 0 \\
\hline Montana & 0.068 & 0 & 0 & 0 & 0.046 & 0 & 0.004 & 0 & 0 \\
\hline Nebraska & 0 & 0 & 0 & 0 & 0 & 0 & 0.001 & 0 & 0 \\
\hline Nevada & 0 & 0.234 & 0 & 0.135 & 0 & 0.163 & 0.003 & 0.304 & 0.353 \\
\hline New & 0 & 0 & 0 & 0 & 0 & 0 & 0.002 & 0 & 0 \\
\hline \multicolumn{10}{|l|}{ Hampshire } \\
\hline New Jersey & 0 & 0 & 0.388 & 0 & 0 & 0 & 0.003 & 0 & 0 \\
\hline New Mexico & 0 & 0 & 0 & 0 & 0 & 0 & 0.004 & 0 & 0 \\
\hline New York & 0.214 & 0 & 0 & 0 & 0.104 & 0 & 0.001 & 0 & 0 \\
\hline North Carolina & 0 & 0.229 & 0 & 0 & 0 & 0 & 0.007 & 0 & 0 \\
\hline North Dakota & 0 & 0 & 0 & 0 & 0 & 0 & 0.001 & 0 & 0.007 \\
\hline Ohio & 0 & 0 & 0 & 0.326 & 0 & 0 & 0.008 & 0 & 0 \\
\hline Oklahoma & 0 & 0 & 0 & 0 & 0 & 0 & 0.024 & 0 & 0 \\
\hline
\end{tabular}




\begin{tabular}{lrrrrrrrrr} 
Oregon & 0 & 0 & 0 & 0 & 0 & 0 & 0.107 & 0 & 0 \\
Pennsylvania & 0 & 0 & 0 & 0 & 0 & 0 & 0.183 & 0 & 0 \\
Rhode Island & 0.191 & 0.005 & 0.024 & 0 & 0 & 0 & 0.012 & 0 & 0.072 \\
South Carolina & 0.029 & 0 & 0.086 & 0 & 0 & 0 & 0.01 & 0 & 0 \\
South Dakota & 0 & 0 & 0 & 0 & 0 & 0 & 0.001 & 0 & 0.114 \\
Tennessee & 0 & 0 & 0 & 0 & 0 & 0.075 & 0.003 & 0 & 0 \\
Texas & 0 & 0 & 0 & 0.107 & 0 & 0 & 0.005 & 0 & 0 \\
Utah & 0 & 0 & 0.126 & 0 & 0 & 0 & 0.001 & 0 & 0 \\
Vermont & 0 & 0 & 0 & 0 & 0 & 0 & 0.002 & 0 & 0 \\
Virginia & 0 & 0 & 0 & 0 & 0 & 0 & 0.006 & 0 & 0 \\
Washington & 0 & 0 & 0 & 0 & 0 & 0 & 0.002 & 0 & 0 \\
West Virginia & 0 & 0 & 0 & 0 & 0 & 0.041 & 0.002 & 0 & 0.107 \\
Wisconsin & 0 & 0 & 0 & 0 & 0 & 0 & 0.003 & 0 & 0 \\
Wyoming & 0 & 0 & 0.042 & 0 & 0 & 0.522 & 0.005 & 0 & 0.011 \\
\hline
\end{tabular}

